УДК 550.42:577.4

\title{
ГИДРОГЕОЛОГИЧЕСКИЕ И ГИДРОЛОГИЧЕСКИЕ УСЛОВИЯ ФУНКЦИОНИРОВАНИЯ ОБСКОГО И БАКСИНСКОГО БОЛОТ (ЮГО-ВОСТОК ЗАПАДНО-СИБИРСКОЙ РАВНИНЫ)
}

\author{
Савичев Олег Геннадьевич 1 , \\ OSavichev@mail.ru \\ Ян Хэнь 1 , \\ 13698754927@163.com \\ 1 Национальный исследовательский Томский политехнический университет, \\ Россия, 634050, г. Томск, пр. Ленина, 30.
}

\begin{abstract}
Актуальность определяется важной комплексной ролью болот в формировании экологического состояния регионов Западной Сибири, включая вопросы взаимодействия подземных, речных и болотных вод.

Цель: исследование гидрогеологических и гидрологических условий функционирования низинных Обского и Баксинского болот на юго-востоке Западно-Сибирской равнины. Основные задачи: 1) оценка элементов водного баланса болот; 2) оценка и анализ взаимодействия болотных, речных и подземных вод.

Методы: статистический анализ, математическое моделирование гидрогеологических и гидрологических процессов.

Результаты и выводы. Выполнена количественная оценка элементов водного баланса Баксинского и Обского болот и их водосборов за 1966-2019 ге. (юго-восточная часть Западно-Сибирской равнины на участках сочленения с палеозойским обрамлением). Определено внутригодовое распределение инфильтрационного питания палеоген-четвертичных отложений в междуречье рек Обь и Шегарка. Показано, что при заболачивании с преимущественным распространением низинных болот происходит уменьшение испарения с поверхности и увеличение слоя водного стока. Это приводит к дополнительному заболачиванию территории. Установлено, что взаимодействие поверхностных и подземных вод с разной степенью интенсивности в основном ограничено глубинами 110-120 м. Влияние болотных вод на подземные воды наиболее вероятно в летнеосенний период. В это время возможен переток болотных вод в подземные горизонты на участках 800-900 м, а также увеличивается инфрильтрационное питание. Влияние болотных вод достигает максимумов на спаде высоких половодий, когда происходит сброс водных масс с заболоченной поймы в речное русло.
\end{abstract}

\section{Ключевые слова:}

Обское болото, Баксинское болото, подземные, речные и болотные воды, водный баланс, Западная Сибирь.

\section{Введение}

Болота Западной Сибири - важный компонент окружающей среды, одновременно определяющий ее общее состояние и являющийся индикатором взаимодействий между объектами лито-, гидро- и биосфер, а в последние десятилетия - и ноосферы [1-4]. Это определяет актуальность болотных исследований, в том числе - гидрогеологических и гидрологических условий функционирования крупных болотных экосистем. Нами эта проблема была рассмотрена на примере низинных Обского и Баксинского болот.

Первое из них (Обское болото) расположено на юго-востоке Западной Сибири (в геологическом отношении - на юго-восточной границе ЗападноСибирской плиты, в гидрогеологическом - на участке сочленения Западно-Сибирского артезианского бассейна (ЗСАБ) и Алтае-Саянской гидрогеологической складчатой области (АСГСО)), в левобережной части долины реки Обь в виде полосы шириной от 1,5 до 7 км и длиной около 100 км; средняя глубина торфяной залежи - 3,2 м, торф низинный гипновый, осоково-гипновый. Тренды среднегодовых значений температуры почвогрунтов на глубине 320 см могут достигать $0,8{ }^{\circ} \mathrm{C} / 10$ лет [5]. Обское болото, согласно Ю.А. Львову [6], относится к Обь-Иртышскому пойменному болотному округу, к Кожевниковскому району низинных гипновых и осоково-гипновых притеррасных болот; по [7] - к Обскому району торфонакопления, а в соответствии с [1] - к подтаежной бо- лотной провинции западносибирских атлантических евтрофных осоково-гипновых болот. Достаточно подробное описание Обского болота приведено в [8-12], гидрогеологических условий непосредственно рядом с Обским болотом (в с. Мельниково) и на прилегающих территориях - в [13-20]. Следует отметить и возможность использования данных о более детально изученном объекте-аналоге - низинном Аркадьевском болоте, расположенном в долине р. Обь к югу от Обского болота [21].

Второе (Баксинское) болото также расположено в пределах подтаежной болотной провинции западносибирских атлантических евтрофных осоковогипновых болот согласно [1], но по Ю.А. Львову [6] уже не в пределах Обь-Иртышского пойменного болотного округа, а на прилегающих к нему территориях Бакчарского (Шегарский болотный район неразвитых водораздельных низинных массивов и осоковогипновых низинных систем на речных террасах) и Васюганского округов (Сенченский болотный район сочетания осоково-гипновых и гипновых евтрофных топей, мезотрофных осоково-сфагновых топей и плосковыпуклых олиготрофных сфагновых островов). На Баксинском болоте в 1961-1969 гг. производились наблюдения за уровнями болотных вод, результаты которых, а также общее описание опубликованы в [22]. Указанные материалы могут быть использованы для оценки элементов водного баланса не только Баксинского, но и Обского болота, поскольку последний 
объект характеризуется близкими условиями торфообразования.

Общая цель исследования - изучение гидрогеологических и гидрологических условий функционирования низинных Обского и Баксинского болот на юго-востоке Западно-Сибирской равнины. Основные задачи связаны с количественной оценкой: 1) элементов водного баланса болот; 2) взаимодействия болотных, речных и подземных вод.

\section{Исходные данные и методика исследования}

Общая методика исследования определяется целью, задачами исследования и имеющимися данными 1) поперечный профиль Обского болота южнее с. Нащеково [9]; 2) поперечный профиль долины реки Обь у с. Мельниково [10]; 3) данные о глубинах торфяной залежи, химическом составе торфов по глубине торфяной залежи и болотных вод в деятельном горизонте торфяной залежи, вещественном составе минеральных включений в торф у сел Мельниково и Нащеково в 2002-2019 гг. [9-12]; 4) среднемесячные уровни болотных вод Баксинского болота в 1961-1969 гг. [22]; 5) данные о режиме подземных вод по результатам гидрогеологических наблюдений на скважинах у с. Мельниково, вскрывающих палеоген-четвертичный, верхнемеловой водоносные комплексы [13-19]; 6) гидрогеологические разрезы ОбьТомского междуречья и междуречий Икса-ШегаркаОбь [16]; 7) характеристики фильтрационных свойств торфов Томской области [23]; 8) морфометрические характеристики, данные о расходах и уровнях воды рек Обь, Шегарка, Бакса, данные о температуре атмосферного воздуха, атмосферных осадках, относительной влажности атмосферного воздуха на метеостанциях Томск, Бакчар, Северное, Болотное, Огурцово (Новосибирск) [22-25] с использованием данных ряда авторов об условиях развития болотных процессов $[1,19,26,27]$ и материалов Росгидромета.

Методика исследования является одновременно и результатом исследования, в процессе которого она корректировалась. В целом она представляет собой последовательность следующих мероприятий:

1) расчет водного баланса водосбора реки Бакса в створе с. Пихтовка, в верхней части которого расположено Баксинское болото, в том числе (морфометрические характеристики водосбора и реки: длина реки от истока $L_{q}=18$ км; площадь водосбора $F_{b}=296$ км ; озерность $f_{\text {fen }}=1 \%$; заболоченность $f_{\text {fen }}=60 \%$; лесистость $f_{\text {frs }}=35 \%$; средняя высота водосбора $Z_{b}=140$ м $\left.[22,24]\right)$ :

1.1) расчет месячных сумм атмосферных осадков $P_{m}(\mathrm{Mм} / \mathrm{Mec})$, среднемесячных значений температуры приземных слоев атмосферного воздуха $T_{m}\left({ }^{\circ} \mathrm{C}\right)$ и дефицита влажности $d_{m}$ (гПа) для геометрического центра водосбора как средневзвешенное по соответствующим данным метеостанций Томск, Бакчар, Северное, Болотное, Огурцово за период с 1966 по 2019 г. (1):

$$
X_{b c}=\frac{\sum \frac{X_{k}}{l_{k}}}{\sum \frac{1}{l_{k}}},
$$

где $X_{b c}$ - искомое значение величины $X$ в геометрическом центре водосбора (за каждый $m$-месяц $j$-го года); $l_{k}$ - расстояние от геометрического центра водосбора до $k$-й метеостанции [28, 29];

1.2) проверка на однородность ряда наблюдений $P_{m}$ по дисперсии (критерий Фишера $\left.k_{F}(2)\right)$ и среднему (критерий Стьюдента $\left.k_{S}(3)\right)$ с целью выделения условно однородного периода (с уровнем значимости $5 \%$ для расчета характеристик среднемноголетнего водного баланса и параметров для расчета испарения:

$$
\begin{gathered}
k_{F}=\frac{D_{1}}{D_{2}}, \\
k_{S}=\frac{\left|A_{1}-A_{2}\right|}{\sqrt{N_{1} D_{1}+N_{2} D_{2}}} \sqrt{\frac{N_{1} N_{2}\left(N_{1}+N_{2}-2\right)}{N_{1}+N_{2}}},
\end{gathered}
$$

где $A_{1}, A_{2}, D_{1}, D_{2}$ - средние арифметические значения и дисперсии для двух выборок объемами $N_{1}$ и $N_{2}$; в формуле (2) в числителе - наибольшее значение, в знаменателе - наименьшее из двух; объемы выборок последовательно изменяются от $(4 ; N-4)$ до $(N-4 ; 4)$, где $N=N_{1}+N_{2}[30]$;

1.3) расчет среднемноголетнего испарения за год $E_{y a}$ (мм/год) для однородного периода по разнице между среднемноголетними значениями слоя атмосферного увлажнения $P_{y a}($ мм/год) и водного стока реки Бакса у с. Пихтовка $Y_{\text {уа }}($ мм/год):

$$
E_{y a}=P_{y a}-Y_{y a}-\Delta W_{b}=P_{y a}-Y_{y a}-\Delta W_{f e n} \Delta f_{f e n^{*}},
$$

где $\Delta W_{b}, \Delta W_{f e n}-$ изменение влагозапасов в водосборе в целом и в болотах в частности (мм/год); $f_{\text {fen }}$ - заболоченность водосбора (в долях единицы); согласно [6, 31], для таежной зоны Западной Сибири скорость прироста торфяной залежи $v_{p d}$ составляет в среднем около $1 \mathrm{мм} /$ год, для верховых болот - 1,15 мм/год, для низинных болот - 0,59 мм/год; с учетом этого при средней влажности торфа $W_{p}=79,2 \%$ низинных болот Кожевниковского района Томской области $[7,21]$ среднемноголетнее значение $\Delta W_{a, f e n}=v_{p d} \cdot W_{p}=1,15 \cdot 0,792 \approx 0,47$ мм/год; заболоченность водосбора реки Бакса в створе с. Пихтовка $f_{\text {fen }}=60 \%$ [24];

1.4) расчет месячных значений испарения $E_{m(-) j}$ (мм/мес) с поверхности водосбора в холодный период (в месяцы с отрицательными среднемесячными температурами воздуха) по уравнению П.П. Кузьмина [22]:

$$
E_{m(-) j}=0,34 d_{m j} N_{m},
$$

где $d_{m j}$ - дефицит влажности за $m$-месяц $j$-го года; $N_{m}$ - количество суток в месяце;

$1.5)$ расчет для каждого $j$-го года испарения с поверхности водосбора за месяцы теплого периода (с положительными среднемесячными температурами воздуха) из предположения о пропорциональности внутригодового изменения испарения и дефицита влажности $[32,33]$ по уравнению (6):

$$
E_{m(+) j}=E_{y a}\left(\frac{d_{m(+) j}}{d_{y a}}\right)^{k_{d}},
$$

где $d_{y a}$ - среднемноголетнее значение дефицита влажности за однородный период (гПа); $k_{d}$ - эмпирический коэффициент, подбираемый из условия: 


$$
K r=100 \frac{\left|E_{y a}-E_{y a s}\right|}{E_{y a}} \rightarrow 0,
$$

где $E_{y a s}($ мм/год) - среднее годовое расчетное испарение за однородный период (сумма месячных значений испарения за теплый и холодный периоды); подбор $k_{d}$ производится подбором с погрешностью не более $1 \%$ (использовался инструмент «поиск решения» в MS Excel c применением метода общего понижающего градиента); для водосбора реки Бакса у с. Пихтовка $k_{d}=0,991$ при $K r=3,45 \cdot 10^{-5} \%$;

1.6) побор параметра $n(M)$ для расчета среднемноголетнего испарения $E_{y a(M)}(\mathrm{Mм} /$ год) с поверхности водосбора по методу гидроклиматических расчетов [33]:

$$
\begin{gathered}
E_{y a(M)}=E_{\max , a}\left(1+\left(\frac{P_{y a}}{E_{\max , a}}\right)^{-n(M)}\right)^{-\frac{1}{n(M)}}, \\
E_{\max , a}=5,1 \sum T_{m(+)}+382,
\end{gathered}
$$

где $E_{\max , a}-$ водный эквивалент теплоэнергетических ресурсов (мм/год); $\Sigma T_{m(+)}$ - сумма положительных температур воздуха за год; подбор $n(M)$ осуществлялся так же, как и в случае $k_{d}$, по условию (7); для водосбора р. Баксы у с. Пихтовка $n(M)=1,684$ при $K r=1,20 \cdot 10^{-6} \%$;

$1.7)$ расчет испарения $E_{m j, f e n}(\mathrm{Mм} / \mathrm{Mec})$ с поверхности болота согласно $[34,35]$ по уравнению (10):

$$
\begin{gathered}
E_{m j, f e n}=k_{r b} R b_{m j}, \\
k_{r b}=13,6+9,88 \cdot 10^{-2} h_{m j, f e n},
\end{gathered}
$$

где $h_{m j, f e n}$ - глубина болотных вод относительно средней поверхности болота (м); $R b_{m j}$ - радиационный баланс деятельной поверхности (кДж/м²); между значениями $R b_{m j}$ и рядом функций температуры воздуха установлены статически значимые связи [33, 36]; с учетом этого и формулы (6) авторами для условий Западной Сибири в теплый период года по данным [37] получена зависимость:

$$
E_{m(+) j, f e n}=4,402 E_{y a}\left(\frac{d_{m(+) j}}{d_{y a}}\right)^{k_{d}}\left(\sum T_{m(+)}\right)^{-0,5},
$$

параметры 4,402 и -0,5 получены при условии минимума функции $\frac{S}{\sigma}(13)$ :

$$
\frac{S}{\sigma}=\sqrt{1-R^{2}}=\sqrt{\frac{\sum\left(X_{o}-X_{s}\right)^{2}}{(N-1) D_{o}}} \rightarrow 0,
$$

где $R^{2}$ - квадрат корреляционного отношения согласно [38]; $X_{o}$ и $X_{s}-$ измеренные и расчетные значения величины $X ; D_{o}$ и $\sigma$ - дисперсия и стандартное отклонение $X_{o} ; N$ - объем выборки; в рассматриваемом случае $\frac{S}{\sigma}=0,45$; сумма положительных температур в (12) рассчитана с начала гидрологического года (с октября);

$1.8)$ расчет максимально возможной месячной водоотдачи из снежного покрова $S_{m j, \max }(\mathrm{Mм} / \mathrm{Mec})$ по уравнению (14), влагозапасов в снежном покрове $V s_{m j}$ (мм) по уравнению (15) и «фактической» водоотдачи из снежного покрова $S_{m j}(\mathrm{~mm} / \mathrm{Mec})$ по уравнению (16):

$$
\begin{gathered}
S_{m j, \max }=k_{T} T_{m j} N_{m}, \\
V s_{m j}=V s_{0}+P_{m(-) j}-S_{m j, \max }-E_{m(-) j}, \\
S_{m j}=\left\{\begin{array}{cc}
V s_{m j-1}-V s_{m j-1}, & V s_{m j-1}-V s_{m j-1}>0 ; \\
0, & V s_{m j-1}-V s_{m j-1} \leq 0,
\end{array}\right.
\end{gathered}
$$

где $k_{T}-$ коэффициент стаивания (принято $k_{T}=5 \mathrm{~mm} /\left(\right.$ сут $\left.\cdot{ }^{\circ} \mathrm{C}\right) ; P_{m(-) j}-$ атмосферные осадки в холодный период (при отрицательных температурах), рассматриваемые условно как снег; начальное значение $V s_{0}=0$ установлено для июля $[39,40]$;

$1.9)$ расчет эффективного увлажнения $H_{m j}(\mathrm{Mm} / \mathrm{Mec})$ :

$$
H_{m j}=S_{m j}+P_{m(+) j},
$$

$P_{m(+) j}$ - атмосферные осадки в теплый период (при положительных среднемесячных температурах воздуха), рассматриваемые условно как дождь;

1.10) расчет изменений влагозапасов в болотах, исходя из условия:

$$
\begin{gathered}
\frac{1}{N_{y}} \sum\left(H_{m j, f e n}-E_{m j, f e n}-k_{Y f} \Delta Y_{m j}\right)= \\
=\Delta W_{a, f e n} \approx 0,47 \mathrm{мм} / \text { год, } \\
\Delta W_{m j, f e n}=\mu_{m j, f e n} \Delta Z_{m j, f w}+\Delta W_{m j, f g}, \\
\Delta Z_{m j, f w}=Z_{m j, f w}-Z_{[m-1] j, f w},
\end{gathered}
$$

где $N y$ - количество расчетных лет; $H_{m j, f e n}, E_{m j, f e n}-$ эффективное увлажнение и испарение с поверхности болота в $m$-месяц $j$-го года $\left(j=1, \ldots, N_{y}\right)$ в мм/мес; $k_{Y f}-$ поправочный коэффициент пересчета слоя стока с водосбора $Y_{m j}$ к слою стока $Y_{m j, f e n}(\mathrm{Mм} / \mathrm{Mec})$ с болот, определяемый подбором по условию (7) при допущении $\Delta W_{a, f e n} \approx 0,47$ мм/год; для водосбора реки Бакса у с. Пихтовка $k_{Y f}=1,612$ при $K r=1,20 \cdot 10^{-2} \% ; \mu_{m j, f e n}-$ коэффициент водоотдачи торфяной залежи (в долях единицы) при изменении уровней болотных вод $Z_{m j, f w}($ м); $\Delta W_{m j, f g}$ - водообмен между болотными и подземными водами (мм/мес); положительное значение $\Delta W_{m j, f g}$ свидетельствует о преобладании притока подземных вод в нижние слои болота по сравнению с фильтрацией болотных вод в подземные горизонты;

1.11) расчет коэффициентов влагопроводности торфяного грунта $k_{m j, f w}(\mathrm{M} / \mathrm{cyт})$ при допущении, что основной водный сток в пределах болот, согласно [34, $41,42]$, приурочен не ко всей торфяной залежи, а к ее верхней части - так называемому деятельному горизонту глубиной $h_{\text {apd }}(\mathrm{м})$ :

$$
\begin{gathered}
Q_{m j, f e n} k_{m j, f w}\left(h_{a p d}-h_{m j, f w}\right) L_{F f}, \\
k_{m j, f w}=\frac{Y_{m j, f e n}}{N_{m}\left(h_{a p d}-h_{m j, f w}\right)} \sqrt{\frac{F_{f e n}}{\pi},}
\end{gathered}
$$

где $Q_{m j, f e n}$ и $Y_{m j, f e n}-$ среднемесячный расход воды $\left(\mathrm{m}^{3} / \mathrm{c}\right)$ и месячный слой водного стока (мм/мес); $h_{m j, f w}-$ глубина болотных вод (м); глубина деятельного горизон- 
та торфяной залежи принята в размере $h_{a p d}=0,75$ м по данным наблюдений на скважине 106 Баксинского болота [22] с учетом данных о распределении концентраций $\mathrm{Fe}$ и $\mathrm{P}$ в кислотных вытяжках из торфов Обского болота 26.11.2018 г. [11, 12]; в последнем случае было установлено резкое изменение концентраций $\mathrm{Fe}$ и $\mathrm{P}$ на границе слоя 0,00-0,75 м, что с большой вероятностью связано с изменением окислительно-восстановительной обстановки вследствие сокращения поступления кислорода (рис. 1); $\pi=3,14 \ldots$; $N_{m}$ - количестве суток в месяце; $F_{f e n}-$ площадь болот в пределах водосбора $\left(\right.$ км $\left.^{2}\right) ; L_{F f}-$ контур водного стока с болот, принят с учетом рекомендаций [41] в размере половины длины окружности с приведенным радиусом $r_{F f}=\sqrt{\frac{F_{f e n}}{\pi}}$, то есть $L_{F f}=\sqrt{F_{f e n} \pi} ;$ в [41] в уравнении (21) рассматривается коэффициент фильтрации $k_{m j, f 0}($ м/сут), но с учетом определенной сопоставимости деятельного горизонта торфяной залежи с зоной аэрации более корректно рассмотрение именно $k_{m j, f w}$, а не $k_{m j, f 0}$; связь между $k_{m j, f w}$ и $k_{m j, f 0}$ принята согласно [43-45] в виде:

$$
k_{m j, f w}=k_{m j, f 0} \exp \left(-k_{w p}\left(n_{p}-\varepsilon_{m j}-\omega_{m j}\right)\right),
$$

где $k_{w p}$ - эмпирический коэффициент; $n_{p}, \varepsilon_{m j}, \omega_{m j}-$ пористость, льдистость и влага (\%);

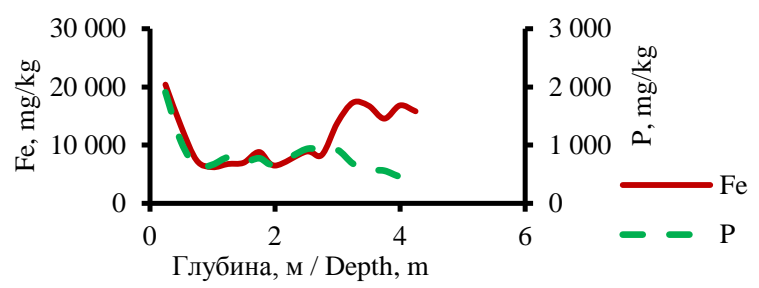

Рис. 1. Изменение концентраций Fe и $\mathrm{P}$ в кислотных вытяжках из торфов Обского болота у с. Нащеково 26.11.2018 г. (по данным $[11,12]$ )

Fig. 1. Change of $\mathrm{Fe}$ and $P$ concentration in acid extracts from peats of the Obskoe fen around Natshchekovo settlement on 26.11.2018 (by the data [11, 12])

1.12) расчет коэффициента водоотдачи болота по уравнению (24) К.П. Лундина [46], водоотдачи из торфяной залежи $\mu_{m j, f e n} \cdot \Delta Z_{m j, f w}$ и водообмена между болотными и подземными водами $\Delta W_{m j, f g}$ по уравнению (19):

$$
\mu_{m j, f e n}=0,13+0,074 \lg k_{m j, f w},
$$

при отсутствии стока и исчезающе малых коэффициентах влагопроводности (с учетом применимости (24)) $\mu_{m j, f e n}=0$;

$1.13)$ расчет влаги в торфе $\omega_{m j}(\%)$ по уравнению (23) при допущении, что льдистость торфа пропорциональна глубине его промерзания:

$$
\varepsilon_{m j}=100 \frac{k_{\varepsilon} \sqrt{\left|\sum T_{m j,<0}\right|}}{h_{\text {apd }}},
$$

где $k_{\varepsilon}$ - эмпирический коэффициент (принято $k_{\varepsilon} \approx 0,93$ по результатам измерения толщины промерзшего слоя торфа на Обском болоте в начале зимнего периода 2018-2019 гг.); $\sum T_{m j,<0}$ - сумма отрицательных среднемесячных температур атмосферного воздуха за предшествующий период гидрологического года (с октября); пористость торфа $n_{p}$ принята в размере $91 \%$ для осоково-гипнового низинного торфа по данным [23]; коэффициент фильтрации $k_{m j, f 0}$ принят равным максимальному значению $k_{m j, f w}$; коэффициент $k_{w p}$ определен подбором по условию (7); для водосбора реки Бакса у с. Пихтовка $\left|k_{w p}\right|=2,641$ при $K r=7,24 \cdot 10^{-8} \%$; в случае $h_{a p d}-h_{m j, f w}<0$ величина $\omega_{m j}$ определена с учетом [43] по зависимости:

$$
\omega_{m j}=\omega_{a}-8 h_{m j, f w},
$$

где $\omega_{a}$ - среднее значение влаги, принятое как среднее значение для торфяных месторождений в водосборе реки Бакса [21] в размере 79,2 \%;

$1.14)$ определение параметров модели слоя суммарного стока с водосбора р. Баксы при допущении (27), на основе которого получена зависимость вида (28):

$$
\begin{gathered}
\frac{d Y}{d t} \approx k_{H}\left(H-E_{(+)}-Y\right), \\
Y_{m j}=\left(H_{m j}-E_{m(+) j}\right)+\left(Y_{[m-1] j}-\left(H_{m j}-E_{m(+) j}\right)\right) \exp \left(-k_{H} \tau\right),
\end{gathered}
$$

где $k_{H} \cdot \tau$ - произведение удельной скорости изменения стока на время добегания водных масс [39, 47], определяемое подбором при условии минимума функции $\frac{S}{\sigma}$; для водосбора р. Бакса у с. Пихтовка $k_{H} \cdot \tau=0,525$ при $\frac{S}{\sigma}=0,79$;

2) расчет водного баланса Обского болота с использованием параметров модели водного баланса Баксинского болота (4)-(28), в том числе:

2.1) оценка морфометрических характеристик водосбора Обского болота: площадь водосбора $F_{b}=2100 \mathrm{kм}^{2}$; заболоченность водосбора (с учетом не только Обского, но и других болот) $f_{f e n}=30 \%$; лесистость $f_{f r s}=15 \%$; расстояние от геометрического центра водосбора $\left(56,787^{\circ}\right.$ с.ш., $84,168^{\circ}$ в.д.) до г. Томска - 60 км, что, согласно $[48,49]$, позволяет использовать в уравнении (1) данные только по метеостанции Томск;

2.2) расчет среднемноголетнего годового испарения по уравнению (8), месячного испарения с поверхности водосбора в холодный и теплый периоды по (5), (6), месячного испарения с поверхности болота в холодный и теплый периоды - по (5), (12), месячного эффективного увлажнения - по (14)-(17); получено для Обского болота: $E_{\max , a}=753,4$ мм/год; $E_{y a(M)}=422 \mathrm{мм} /$ год;

$2.3)$ подбор коэффициента $k_{Y f}$ в (18) и расчет месячного слоя стока с болота и изменение влагозапасов в болоте по (19); для Обского болота $k_{Y f}=1,048$ при $K r=9,17 \cdot 10^{-4}$;

2.4) расчет коэффициентов влагопроводности по (22), влаги в торфе - по (23), (26), коэффициентов водоотдачи торфа - по (24); для Обского болота $k_{w p}=1,334$ при $K r=8,33 \cdot 10^{-8}$;

2.5) анализ полученных рядов слоев эффективного увлажнения, испарения, стока и изменений влаго- 
запасов на однородность по критериям Фишера и Стьюдента (2), (3) при уровне значимости $5 \%$, расчет статистических параметров: среднего арифметического $A$, погрешности его определения $\delta_{A}(29)$; коэффициента вариации $C v$; коэффициента асимметрии Cs:

$$
\delta_{A} \approx \frac{\sigma}{\sqrt{N}},
$$

где $N$ - объем выборки; $\sigma$ - среднее квадратическое отклонение;

3) расчет инфильтрационного питания подземных водоносных горизонтов в междуречье Обь-Шегарка и анализ взаимодействия речных, подземных и болотных вод с учетом результатов анализа водного баланса Баксинского и Обского болот:

3.1) расчет инфильтрационного питания $I_{b}$ (мм/мес) по данным о среднемесячных уровнях воды р. Оби у с. Победа (расстояние от слияния рек Бия и Катунь $L_{q}=928$ км; площадь водосбора $F_{b}=264000$ км$^{2}$ [24]) и р. Шегарки у с. Бабарыкино (р. Бакса - приток p. Шегарки; морфометрические характеристики водосбора р. Шегарки у с. Бабарыкино: длина реки от истока $L_{q}=205$ км; площадь водосбора $F_{b}=8190 \mathrm{\kappa м}^{2}$; озерность $f_{\text {fen }}=1 \%$; заболоченность $f_{\text {fen }}=25 \%$; лесистость $f_{f r s}=45 \%$; средняя высота водосбора $Z_{b}=130 \mathrm{м}$ $[22,24])$, среднемесячных уровнях подземных вод в скважине 63p (водоносный комплекс в отложениях возраста $\left.2 \mathrm{aQ}_{\mathrm{III}}+\mathrm{P}_{3} \mathrm{lt}\right)$ на окраине с. Мельниково $[13,15$ по уравнению Дюпюи при допущении горизонтального залегания водоупора $[45,50]$ :

$$
I_{b}=k_{f 0} k_{m}\left(\frac{Z_{g}^{2}-Z_{r S}^{2}}{\left(L_{S O}-L_{S g}\right) L_{S g}}+\frac{Z_{r S}^{2}-Z_{r O}^{2}}{\left(L_{S O}-L_{S g}\right) L_{S O}}\right),
$$

где $k_{f 0}$ - средневзвешенное значение коэффициента фильтрации (м/сут); $k_{m}$ - коэффициент размерности (от м/сут к мм/мес); $Z_{g}$ - уровень подземных вод у с. Мельниково (м); $Z_{r S}-$ уровень воды в р. Шегарка у с. Бабарыкино (м); $Z_{r O}-$ уровень воды в р. Оби у п. Победа $(\mathrm{м}) ; L_{S O}$ и $L_{S g}-$ расстояние между урезами воды в створах на pр. Оби и Шегарки и от р. Шегарки до с. Мельниково $\left(L_{S O}=34000\right.$ м); подбор $k_{f 0}$ выполнен по критерию вида (7) при допущении примерного равенства инфильтрационного питания и подземного стока р. Шегарки у с. Бабарыкино в среднем за многолетний период (1965-2000 гг.); оценка подземной составляющей $Y_{g, m j}$ месячного стока р. Шегарки $Y_{m j}$ выполнена по уравнению:

$$
Y_{g, m j}=\left\{\begin{array}{cc}
Y_{m j} & m=1,2,3,12 ; \\
Y_{3 j}+\left(Y_{12 j}-Y_{3 j}\right) \frac{m-3}{12-3} & m=4, \ldots, 11,
\end{array}\right.
$$

где $m$ - номер месяца календарного года $j$ (с января); слой суммарного водного стока р. Шегарки у с. Бабарыкино составляет 64,0 мм/год, его подземная составляющая - 10,4 мм/год или $16,3 \%$ от суммарного стока; с учетом этого $k_{f 0}=9,88$ м/сут;

3.2) обобщение и анализ полученных данных, включая оценку изменения уровней подземных вод по схематическому разрезу долины р. Оби и статистический анализ с учетом требований [28]; корреля- ционные связи принимались статистически значимыми (с уровнем значимости $5 \%$ ) при соблюдении условий $|r| \geq \frac{2\left(1-r^{2}\right)}{\sqrt{N-2}}$ и $|r| \geq 0,70$, а регрессионные - при условии $R^{2}>0,36$ и $\left|k_{r}\right| \geq \delta_{k}$, где $r$ - коэффициент корреляции; $k_{r}$ - коэффициент регрессии; $\delta_{k}-$ погрешность определения коэффициента регрессии; $N$ - объем выборки; $R^{2}$ - квадрат корреляционного отношения (13); все вычисления выполнены в пакете MS Excel.

\section{Результаты исследования и их обсуждение}

Анализ годовых сумм атмосферных осадков в геометрическом центре водосбора р. Баксы у с. Пихтовка позволил выявить (с уровнем значимости 5 \%) условно однородный период с 1966-1975 гг. С учетом этого, а также принимая во внимание период наблюдений за уровнями вод Баксинского болота 1961-1969 гг. [22], по уравнениям (4)-(31) выполнен расчет элементов водного баланса водосбора р. Баксы у с. Пихтовка (табл. 1) и болот на этой территории (табл. 2). Сравнение результатов расчета показало, что сток с болот составляет примерно $161 \%$ от суммарного стока с водосбора р. Баксы, а испарение с болот - около 83 \% от суммарного испарения с поверхности водосбора. Следствием более высоких значений слоя стока на болоте является накопление воды на его границе, что способствует заболачиванию суходолов.

Характер водообмена болота с подземными водоносными горизонтами определяется сперва некоторым накоплением воды в период снеготаяния, затем притоком (в мае-июне) подземных вод с прилегающих неболотных территорий и увеличением инфильтрации в августе-октябре (табл. 2, рис. 2).

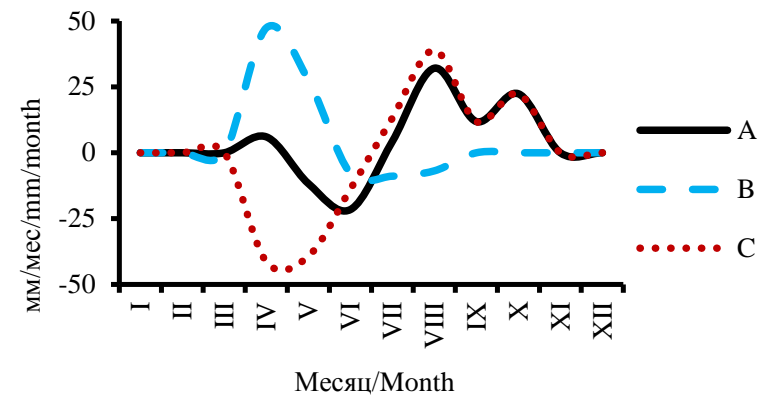

Pис. 2. Внутригодовое изменение (в среднем за многолетний период) влагозапасов (A), водоотдачи из торфяной залежи (В) $и$ водообмена между болотными и подземными водами (C) на Баксинском болоте; расчет по уравнению (19)

Fig. 2. Intraannual change (on the average for the longterm period) of water resources (A), waterfeedbacks from a peat deposit $(B)$ and water exchange between fen and ground waters $(C)$ on the Baksinskoe fen; calculation on the equation (19)

С использованием параметров в уравнениях (6), (8), (12), (28), полученных для водосбора р. Баксы, выполнена оценка элементов водного баланса Обского болота и его водосбора за 1966-2019 гг. Проверка 
на однородность выборок за периоды 1966-1992 гг. и 1993-2019 гг. показала, что значимое изменение отмечено только для расчетных слоев водного стока с болота: фактическое значение критерия Стьюдента $k_{S}=2,17$ при критическом значении $k_{S, 5 \%}=2,01$. Нарушение однородности также отмечено при разделении ряда 1966-2019 гг. на границе с 1982 по 1986 гг. и с 1989 по 1994 гг., однако при разделении ряда по годам за пределами указанных интервалов гипотеза об однородности не отвергнута. Для величины $\Delta W$ значимые изменения не выявлены для всего ряда 1966-2019 гг. С учетом этого указанный период ориентировочно можно рассматривать как однородный с точки зрения условий формирования водного режима Обского баланса.

Для Обского болота, так же как и для Баксинского, испарение с болота меньше испарения с водосбора в целом, а сток, напротив, больше, но уже не на 161 \%, а только на 105 \% (табл. 3). Коэффициенты влагопроводности торфов резко возрастают во время весеннего половодья, но в Баксинском болоте уже в июле они резко снижаются, тогда как в Обском болоте достаточно высокие значения $k_{f w}$, вычисленные по уравнению (12), сохраняются на начало зимней межени (рис. 3).

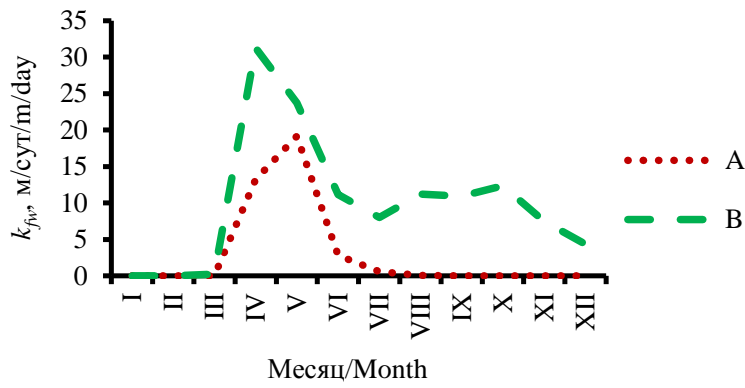

Pис. 3. Внутригодовое изменение (в среднем за многолетний период) коэффиичентов влагопроводности $k_{f w}$ (22) торфов Баксинского (А) и Обского (B) болот

Fig. 3. Intraannual change (on the average for the longterm period) of moisture conductivity factors $k_{f w}(22)$ of peats of the Baksinsloe $(A)$ and Obskoe $(B)$ fens

Таблица 1. Месячные и годовые значения слоя водного стока $Y$ (по измеренным расходам воды Q), эффективного увлажнения $H$ (17), испарения E (сумма значений по уравнениям (5), (6)), изменений влагозапасов $\Delta W$ $(\Delta W=H-E-Y)$ в водосборе р. Баксы у с. Пихтовка

Table 1. Monthly and annual values of a water flow layer $Y$ (under the measured charges of water $Q$ ), effective humidifying $H(17)$, evaporation $E$ (the sum of values on the equations (5), (6)), changes of water resources $\Delta W$ $(\Delta W=H-E-Y)$ in the Baksa river basin at Pikhtovka cross-section

\begin{tabular}{|c|c|c|c|c|c|c|c|c|c|c|c|c|c|c|}
\hline $\begin{array}{l}\text { Параметр, мм } \\
\text { Index, mm }\end{array}$ & Год/Year & I & II & III & IV & V & VI & VII & VIII & IX & $\mathrm{X}$ & XI & XII & X-IX \\
\hline \multirow[t]{9}{*}{$Y$} & 1966 & 0 & 0 & 0 & 3 & 69 & 10 & 3 & 0 & 0 & 0 & 0 & 0 & 86 \\
\hline & 1967 & 0 & 0 & 0 & 7 & 0 & 0 & 0 & 0 & 0 & 0 & 0 & 0 & 8 \\
\hline & 1968 & 0 & 0 & 0 & 1 & 0 & 0 & 0 & 0 & 0 & 0 & 0 & 0 & 1 \\
\hline & 1969 & 0 & 0 & 0 & 26 & 60 & 6 & 0 & 0 & 0 & 0 & 0 & 0 & 93 \\
\hline & 1970 & 0 & 0 & 0 & 23 & 5 & 1 & 1 & 4 & 1 & 3 & 3 & 0 & 35 \\
\hline & 1971 & 0 & 0 & 0 & 56 & 37 & 13 & 3 & 0 & 0 & 0 & 0 & 0 & 115 \\
\hline & 1972 & 0 & 0 & 0 & 28 & 12 & 31 & 37 & 11 & 8 & 12 & 6 & 2 & 127 \\
\hline & 1973 & 1 & 1 & 1 & 178 & 64 & 11 & 3 & 0 & 0 & 0 & 0 & 0 & 279 \\
\hline & 1974 & 0 & 0 & 0 & 23 & 23 & 35 & 9 & 0 & 0 & 0 & 0 & 0 & 90 \\
\hline \multirow[t]{9}{*}{$H$} & 1966 & 0 & 0 & 0 & 0 & 192 & 63 & 35 & 41 & 15 & 0 & 0 & 0 & 382 \\
\hline & 1967 & 0 & 0 & 0 & 131 & 25 & 74 & 69 & 60 & 39 & 20 & 0 & 0 & 397 \\
\hline & 1968 & 0 & 0 & 0 & 63 & 39 & 34 & 77 & 43 & 32 & 29 & 0 & 0 & 310 \\
\hline & 1969 & 0 & 0 & 0 & 0 & 192 & 36 & 61 & 97 & 41 & 69 & 0 & 0 & 457 \\
\hline & 1970 & 0 & 0 & 0 & 83 & 36 & 68 & 91 & 100 & 12 & 0 & 0 & 0 & 461 \\
\hline & 1971 & 0 & 0 & 0 & 154 & 62 & 44 & 50 & 105 & 19 & 27 & 0 & 0 & 434 \\
\hline & 1972 & 0 & 0 & 0 & 114 & 43 & 116 & 62 & 72 & 46 & 38 & 0 & 0 & 480 \\
\hline & 1973 & 0 & 0 & 0 & 133 & 48 & 72 & 125 & 26 & 21 & 35 & 0 & 0 & 463 \\
\hline & 1974 & 0 & 0 & 0 & 126 & 65 & 69 & 23 & 68 & 78 & 0 & 0 & 0 & 465 \\
\hline \multirow[t]{9}{*}{$E$} & 1966 & 4 & 4 & 10 & 19 & 46 & 72 & 85 & 66 & 56 & 17 & 6 & 2 & 409 \\
\hline & 1967 & 4 & 4 & 12 & 39 & 66 & 76 & 79 & 43 & 31 & 23 & 6 & 5 & 381 \\
\hline & 1968 & 4 & 5 & 13 & 30 & 69 & 73 & 74 & 55 & 30 & 20 & 4 & 3 & 389 \\
\hline & 1969 & 2 & 2 & 7 & 19 & 39 & 90 & 103 & 36 & 35 & 13 & 9 & 4 & 360 \\
\hline & 1970 & 4 & 5 & 9 & 29 & 64 & 75 & 51 & 38 & 44 & 10 & 8 & 4 & 344 \\
\hline & 1971 & 4 & 3 & 9 & 31 & 50 & 77 & 67 & 45 & 44 & 30 & 9 & 4 & 352 \\
\hline & 1972 & 4 & 3 & 9 & 31 & 50 & 77 & 67 & 45 & 44 & 30 & 9 & 4 & 373 \\
\hline & 1973 & 3 & 4 & 9 & 32 & 48 & 74 & 57 & 57 & 51 & 21 & 6 & 4 & 378 \\
\hline & 1974 & 3 & 3 & 8 & 32 & 56 & 69 & 78 & 48 & 20 & 13 & 5 & 3 & 348 \\
\hline \multirow[t]{9}{*}{$\Delta W$} & 1966 & 0 & 0 & 0 & -3 & 77 & -19 & -53 & -25 & -42 & 0 & 0 & 0 & -61 \\
\hline & 1967 & 0 & 0 & 0 & 84 & -42 & -2 & -10 & 16 & 8 & -3 & 0 & 0 & 54 \\
\hline & 1968 & 0 & 0 & 0 & 33 & -30 & -39 & 3 & -12 & 3 & 9 & 0 & 0 & -46 \\
\hline & 1969 & 0 & 0 & 0 & -26 & 94 & -60 & -42 & 61 & 6 & 56 & 0 & 0 & 41 \\
\hline & 1970 & 0 & 0 & 0 & 31 & -33 & -7 & 39 & 58 & -32 & -3 & -3 & 0 & 112 \\
\hline & 1971 & 0 & 0 & 0 & 68 & -25 & -46 & -20 & 60 & -25 & -3 & 0 & 0 & 6 \\
\hline & 1972 & 0 & 0 & 0 & 56 & -19 & 8 & -41 & 16 & -7 & -4 & -6 & -2 & 10 \\
\hline & 1973 & -1 & -1 & -1 & -77 & -64 & -13 & 65 & -31 & -30 & 14 & 0 & 0 & -164 \\
\hline & 1974 & 0 & 0 & 0 & 71 & -14 & -35 & -63 & 19 & 58 & 0 & 0 & 0 & 50 \\
\hline
\end{tabular}


Таблица 2. Месячные и годовые значения слоя водного стока $Y_{\text {fen }}(18)$, эффективного увлажнения $H_{\text {fen }}(17)$, исnарения $E_{f e n}$ (сумма значений по уравнениям (5), (12)), изменений влагозапасов $\Delta W_{f e n}\left(\Delta W_{f e n}=H-E_{f e n}-Y_{f e n}\right)$, водоотдачи из торфяной залежи $\mu_{f e n} \Delta Z_{f w}$ и водообмена между болотными и подземными водами $\Delta W_{f g} н а$ Баксинском болоте

Table 2. Monthly and annual values of a water flow layer $Y_{\text {fen }}(18)$, effective humidifying $H_{\text {fen }}(17)$, evaporation $E_{f e n}($ the sum of values on the equations (5), (12)), changes of water resources $\Delta W_{f e n}\left(\Delta W_{f e n}=H-E_{f e n}-Y_{f e n}\right)$, waterfeedbacks from peat deposit $\mu_{f e n} \Delta Z_{f w}$ and water exchange between fen and ground waters $\Delta W_{f g}$ on the Baksinskoe fen

\begin{tabular}{|c|c|c|c|c|c|c|c|c|c|c|c|c|c|c|}
\hline $\begin{array}{l}\text { Параметр, мм } \\
\text { Index, mm }\end{array}$ & $\begin{array}{l}\text { Год } \\
\text { Year }\end{array}$ & I & II & III & IV & V & VI & VII & VIII & IX & $X$ & XI & XII & X-IX \\
\hline \multirow[t]{9}{*}{$Y_{f e n}}$, & 1966 & 0 & 0 & 0 & 5 & 111 & 17 & 4 & 0 & 0 & 0 & 0 & 0 & 138 \\
\hline & 1967 & 0 & 0 & 0 & 12 & 1 & 0 & 0 & 0 & 0 & 0 & 0 & 0 & 13 \\
\hline & 1968 & 0 & 0 & 0 & 1 & 0 & 0 & 0 & 0 & 0 & 0 & 0 & 0 & 2 \\
\hline & 1969 & 0 & 0 & 0 & 42 & 97 & 10 & 0 & 0 & 0 & 0 & 0 & 0 & 149 \\
\hline & 1970 & 0 & 0 & 0 & 37 & 8 & 1 & 2 & 7 & 1 & 4 & 5 & 0 & 57 \\
\hline & 1971 & 0 & 0 & 0 & 89 & 60 & 21 & 5 & 1 & 0 & 0 & 0 & 0 & 185 \\
\hline & 1972 & 0 & 0 & 0 & 45 & 19 & 49 & 60 & 18 & 14 & 20 & 9 & 3 & 204 \\
\hline & 1973 & 2 & 1 & 1 & 287 & 103 & 19 & 5 & 0 & 0 & 0 & 0 & 0 & 449 \\
\hline & 1974 & 0 & 0 & 0 & 37 & 37 & 56 & 14 & 1 & 0 & 0 & 0 & 0 & 145 \\
\hline \multirow[t]{9}{*}{$E_{\text {fen }}$} & 1966 & 4 & 4 & 10 & 19 & 67 & 63 & 56 & 37 & 29 & 17 & 6 & 2 & 319 \\
\hline & 1967 & 4 & 4 & 12 & 62 & 75 & 60 & 49 & 24 & 16 & 12 & 6 & 5 & 331 \\
\hline & 1968 & 4 & 5 & 13 & 47 & 83 & 62 & 48 & 31 & 16 & 11 & 4 & 3 & 333 \\
\hline & 1969 & 2 & 2 & 7 & 19 & 61 & 82 & 67 & 21 & 19 & 7 & 9 & 4 & 297 \\
\hline & 1970 & 4 & 5 & 9 & 46 & 83 & 64 & 34 & 22 & 23 & 10 & 8 & 4 & 310 \\
\hline & 1971 & 4 & 3 & 9 & 49 & 64 & 65 & 44 & 25 & 23 & 15 & 9 & 4 & 309 \\
\hline & 1972 & 4 & 3 & 9 & 49 & 63 & 65 & 45 & 26 & 25 & 16 & 9 & 4 & 317 \\
\hline & 1973 & 3 & 4 & 9 & 51 & 61 & 60 & 37 & 32 & 26 & 11 & 6 & 4 & 312 \\
\hline & 1974 & 3 & 3 & 8 & 51 & 65 & 56 & 50 & 27 & 11 & 13 & 5 & 3 & 294 \\
\hline \multirow[t]{9}{*}{$\Delta W_{\text {fen }}$} & 1966 & 0 & 0 & 0 & -5 & 14 & -17 & -26 & 4 & -14 & 0 & 0 & 0 & -24 \\
\hline & 1967 & 0 & 0 & 0 & 57 & -51 & 14 & 20 & 36 & 23 & 9 & 0 & 0 & 99 \\
\hline & 1968 & 0 & 0 & 0 & 15 & -44 & -27 & 29 & 12 & 16 & 18 & 0 & 0 & 9 \\
\hline & 1969 & 0 & 0 & 0 & -42 & 34 & -56 & -6 & 76 & 22 & 62 & 0 & 0 & 48 \\
\hline & 1970 & 0 & 0 & 0 & 0 & -55 & 3 & 55 & 71 & -12 & -4 & -5 & 0 & 125 \\
\hline & 1971 & 0 & 0 & 0 & 16 & -62 & -42 & 1 & 79 & -4 & 11 & 0 & 0 & -21 \\
\hline & 1972 & 0 & 0 & 0 & 21 & -40 & 2 & -42 & 28 & 8 & 2 & -9 & -3 & -12 \\
\hline & 1973 & -2 & \begin{tabular}{|c|}
-1 \\
\end{tabular} & -1 & -205 & -116 & -7 & 83 & -6 & -5 & 24 & 0 & 0 & -269 \\
\hline & 1974 & 0 & 0 & 0 & 38 & $\begin{array}{l}-37 \\
\end{array}$ & $\begin{array}{l}-43 \\
\end{array}$ & -40 & 41 & 68 & 0 & 0 & 0 & 50 \\
\hline \multirow[t]{4}{*}{$\mu_{f e n} \Delta Z_{f w}$} & 1966 & 0 & 0 & 0 & 3 & 12 & -11 & -20 & -27 & 0 & 0 & 0 & 0 & -43 \\
\hline & 1967 & 0 & 0 & 0 & 87 & 15 & -7 & 0 & 0 & 0 & 0 & 0 & 0 & 94 \\
\hline & 1968 & 0 & 0 & 0 & 26 & -5 & 0 & 0 & 0 & 0 & 0 & 0 & 0 & 21 \\
\hline & 1969 & 0 & 0 & 0 & 74 & 88 & -12 & -15 & 0 & 0 & 0 & 0 & 0 & 135 \\
\hline \multirow{4}{*}{$\Delta W_{f g}$} & 1966 & 0 & 0 & 0 & -8 & 1 & -5 & -6 & 31 & -14 & 0 & 0 & 0 & 19 \\
\hline & 1967 & 0 & 0 & 0 & -30 & -65 & 21 & 20 & 36 & 23 & 9 & 0 & 0 & 4 \\
\hline & 1968 & 0 & 0 & 0 & -11 & -39 & -27 & 29 & 12 & 16 & 18 & 0 & 0 & -11 \\
\hline & 1969 & 0 & 0 & 0 & -116 & -54 & -43 & 10 & 76 & 22 & 62 & 0 & 0 & -87 \\
\hline
\end{tabular}

Примечание: положительные значения $\Delta W_{\text {fеп }}$ связаны с аккумулячией воды в торфяной залежи, $\Delta W_{f g}-c$ увеличением водоотдачи из торфяной залежи в рассматриваемом месяце по сравнению с предыдущим, $\Delta W_{f g}-c$ увеличением инфильтрации; отрицательные значения $\Delta W_{\text {fen }}$ и $\Delta W_{f g}$ связаны с притоком подземных вод в нижсие горизонты торфяной залежи, $\Delta W_{f g}-$ с уменьшением водоотдачи из торфяной залежи.

Note: positive values $\Delta W_{f e n}$ are associated with water accumulation in the peat deposit, $\Delta W_{f g}$ is associated with increase in fluid loss from the peat deposit in the considered month compared to the previous one, $\Delta W_{f g}$ is associated with increase in infiltration; negative values $\Delta W_{f e n}$ and $\Delta W_{f g}$ are associated with groundwater inflow into the lower horizons of the peat deposit, $\Delta W_{f g}$ is associated with the decrease in fluid loss from the peat deposit.

Безусловно, выполненные расчеты сопряжены со значительными погрешностями (с учетом погрешностей измерения исходных величин - до 10-20 \% [51]), но все же можно предположить, что расположение болота в долине такой большой реки, как Обь, оказывает существенное влияние на его водный режим, фильтрационные свойства торфов и, как следствие, эволюцию весей болотной экосистемы. В частности, долинное Обское болото, в сравнении с Баксинским, в большей степени ограничено в дальнейшем территориальном расширении и характеризуется более интенсивным водообменом с подземными горизонтами. Последнее обстоятельство обеспечивает постоянство водно-минерального питания болотной растительности. В Баксинском же болоте (точнее, на его отдельных участках, сложенных глинистыми грунтами) более вероятна постепенная кольматация пограничного слоя в нижней части торфяной залежи с постепенным распространением растительности, лучше приспособленной к мезотрофным и затем олиготрофным условиям. Все это может приводить к формированию среди пространства евтрофных болот островов олиготрофного ряма (сосново-сфагновокустарничковых верховых болот), подробное описание которых приведено, например, в [52]. 
Таблица 3. Средние арифметические А, погрешности их определения $\delta_{A}(29)$, коэффициенты вариации (Cv) и асимметрии (Cs) значений элементов месячного и годового водного баланса водосбора (без индекса) и непосредственно Обского болота (индекс «fеп»): эффективного увлажнения H (17), водного стока $Y(28)$, испарения Е (5), (6), (12), изменений влагозапасов $\Delta W$

Table 3. Average arithmetic values A, errors of their definition $\delta_{A}(29)$, factors of a variation $(C v)$ and asymmetry $(C s)$ values of elements of monthly and annual water balance of basins (without an index) and fens (an index "fen»): effective humidifying $H(17)$, water drain $Y(28)$, evaporation $E(5),(6),(12)$, changes of moisture content $\Delta W$

\begin{tabular}{|c|c|c|c|c|c|c|c|c|c|c|c|c|c|c|}
\hline $\begin{array}{l}\text { Параметр, мм } \\
\text { Index, mm }\end{array}$ & $\begin{array}{l}\text { Статистика } \\
\text { Statistics }\end{array}$ & I & II & III & IV & V & VI & VII & VIII & IX & X & XI & XII & X-IX \\
\hline \multirow[t]{4}{*}{$H$} & $A, \mathrm{MM}$ & 0 & 0 & 1 & 139 & 95 & 63 & 72 & 68 & 47 & 41 & 0 & 0 & 526 \\
\hline & $\delta_{A}, \mathrm{MM}$ & 0,00 & 0,01 & 0,32 & 12,22 & 10,17 & 3,51 & 4,91 & 4,13 & 3,59 & 3,76 & 0,00 & 0,00 & 11,61 \\
\hline & $C v$ & - & 7,35 & 2,56 & 0,64 & 0,79 & 0,41 & 0,50 & 0,44 & 0,56 & 0,68 & - & - & 0,16 \\
\hline & Cs & - & 7,35 & 2,74 & $-0,35$ & 1,22 & 0,73 & 0,33 & 0,11 & 1,33 & 0,02 & - & - & 0,11 \\
\hline \multirow[t]{4}{*}{$Y$} & $A, \mathrm{MM}$ & 0 & 0 & 0 & 45 & 36 & 16 & 12 & 15 & 14 & 18 & 11 & 6 & 174 \\
\hline & $\delta_{A}, \mathrm{MM}$ & 0,00 & 0,00 & 0,13 & 4,18 & 3,22 & 2,31 & 2,14 & 1,80 & 1,93 & 1,72 & 1,02 & 0,60 & 10,19 \\
\hline & $C v$ & - & 7,35 & 2,55 & 0,69 & 0,65 & 1,06 & 1,29 & 0,86 & 0,98 & 0,71 & 0,71 & 0,71 & 0,43 \\
\hline & $C s$ & - & 7,35 & 2,72 & $-0,05$ & 0,52 & 1,16 & 1,23 & 0,28 & 1,49 & 0,22 & 0,22 & \begin{tabular}{|l|}
0,22 \\
\end{tabular} & 0,24 \\
\hline \multirow[t]{4}{*}{$Y_{\text {fen }}$} & $A, \mathrm{MM}$ & 0 & 0 & 0 & 47 & 38 & 17 & 13 & 16 & 15 & 19 & 11 & 7 & 182 \\
\hline & $\delta_{A}, \mathrm{MM}$ & 0,00 & 0,00 & 0,14 & 4,38 & 3,38 & 2,43 & 2,24 & 1,89 & 2,02 & 1,80 & 1,07 & 0,63 & 10,68 \\
\hline & $C v$ & - & 7,35 & 2,55 & 0,69 & 0,65 & 1,06 & 1,29 & 0,86 & 0,98 & 0,71 & 0,71 & 0,71 & 0,43 \\
\hline & Cs & - & 7,35 & 2,72 & $-0,05$ & 0,52 & 1,16 & 1,23 & 0,28 & 1,49 & 0,22 & 0,22 & 0,22 & 0,24 \\
\hline \multirow[t]{4}{*}{$E$} & $A$, мм & 4 & 5 & 12 & 35 & 70 & 85 & 78 & 54 & 38 & 21 & 7 & 4 & 414 \\
\hline & $\delta_{A}, \mathrm{MM}$ & 0,16 & 0,19 & 0,42 & 1,43 & 2,09 & 2,76 & 2,54 & 1,68 & 1,31 & 0,79 & 0,23 & 0,15 & 6,58 \\
\hline & $C v$ & 0,30 & 0,29 & 0,26 & 0,30 & 0,22 & 0,24 & 0,24 & 0,23 & 0,25 & 0,28 & 0,26 & 0,25 & 0,12 \\
\hline & $C s$ & $-0,20$ & \begin{tabular}{|l|}
0,34 \\
\end{tabular} & 0,73 & $-0,27$ & 0,38 & 0,40 & 0,42 & 0,06 & 0,55 & 0,02 & 0,70 & 0,29 & 0,40 \\
\hline \multirow[t]{4}{*}{$E_{f e n}$} & $A$, мM & 4 & 5 & 12 & 78 & 88 & 70 & 50 & 30 & 20 & 12 & 7 & 4 & 379 \\
\hline & $\delta_{A}, \mathrm{MM}$ & 0,16 & 0,19 & 0,42 & 4,57 & 2,27 & 2,08 & 1,62 & 0,90 & 0,67 & 0,35 & 0,23 & 0,15 & 6,37 \\
\hline & $C v$ & 0,30 & 0,29 & 0,26 & 0,43 & 0,19 & 0,22 & 0,24 & 0,22 & 0,25 & 0,22 & 0,26 & 0,25 & 0,12 \\
\hline & $C s$ & $-0,20$ & 0,34 & 0,73 & $-0,93$ & 0,85 & 0,19 & 0,40 & 0,04 & 0,56 & 1,25 & 0,70 & 0,29 & 0,05 \\
\hline \multirow[t]{4}{*}{$\Delta W$} & $A$, мм & 0 & 0 & 1 & 64 & -12 & -39 & -19 & -2 & -5 & 5 & -11 & -6 & -24 \\
\hline & $\delta_{A}, \mathrm{MM}$ & 0,00 & 0,00 & 0,19 & 6,04 & 8,24 & 3,94 & 5,07 & 3,88 & 3,01 & 2,24 & 1,02 & 0,60 & 6,68 \\
\hline & $C v$ & - & 7,35 & 2,56 & 0,69 & $-5,08$ & $-0,75$ & $-1,97$ & $-17,96$ & $-4,14$ & 3,32 & $-0,71$ & $-0,71$ & $-2,05$ \\
\hline & Cs & - & 7,35 & 2,74 & $-0,05$ & 1,05 & $-0,05$ & $-0,26$ & $-0,16$ & 0,15 & $-0,30$ & $-0,22$ & $-0,22$ & $-1,56$ \\
\hline \multirow[t]{4}{*}{$\Delta W_{\text {fen }}$} & $A, \mathrm{MM}$ & 0 & 0 & 1 & 20 & -31 & -24 & 9 & 22 & 12 & 13 & -11 & -7 & 3 \\
\hline & $\delta_{A}$, MM & 0,00 & 0,00 & 0,18 & 4,94 & 7,53 & 3,56 & 4,35 & 3,42 & 2,52 & 2,45 & 1,07 & 0,63 & 6,60 \\
\hline & $C v$ & - & 7,35 & 2,56 & 1,85 & $-1,79$ & $-1,09$ & 3,66 & 1,15 & 1,51 & 1,40 & $-0,71$ & $-0,71$ & 14,38 \\
\hline & $C s$ & - & 7,35 & 2,74 & 0,67 & 1,02 & 0,05 & $-0,09$ & $-0,11$ & 0,37 & $-0,63$ & $-0,22$ & $-0,22$ & $-0,56$ \\
\hline
\end{tabular}

Результаты расчета водообмена между подземными водами и водами Баксинского и Обского болот в целом согласуются с расчетами по уравнению (30) инфильтрации на междуречье рек Обь и Шегарка (рис. 4). В период весеннего половодья в результате таяния снега, водоотдачи из снегового покрова и оттаивания сезонно промерзших грунтов снеготаяния происходит увеличение влажности и коэффициентов влагопроводности грунтов и водоотдачи из торфяных болот (рис. 2)

При этом скорость условно горизонтального перемещения водных масс на поверхности и в подземных водоносных горизонтах в русловую сеть и понижения рельефа превышает скорость инфильтрации. Это приводит к снижению удельной инфильтрации на междуречном пространстве на фоне общего увеличения уровней подземных вод и отсутствия подпора от р. Оби (рис. 4).

Максимумы же инфильтрации приурочены к осеннему периоду (рис. 2, 4, табл. 2, 3), когда совпадают три условия: 1) эффективное атмосферное увлажнение (дожди в конце лета и осенью при снижении испарения); 2) относительно благоприятные фильтрационные свойства грунтов (отсутствие пересыхания и перемерзания верхних слоев геологического разреза); 3) освобождающаяся емкость подземных горизонтов. Отсутствие какого-либо из указанных факторов приводит к нестабильному и плохо прогнозируемому поступлению влаги в подземные водоносные горизонты, о чем косвенно свидетельствуют отрицательные результаты подбора регрессионных зависимостей инфильтрации по уравнению (30) от различных климатических и гидрологических факторов $\left(R^{2}<0,36\right)$.

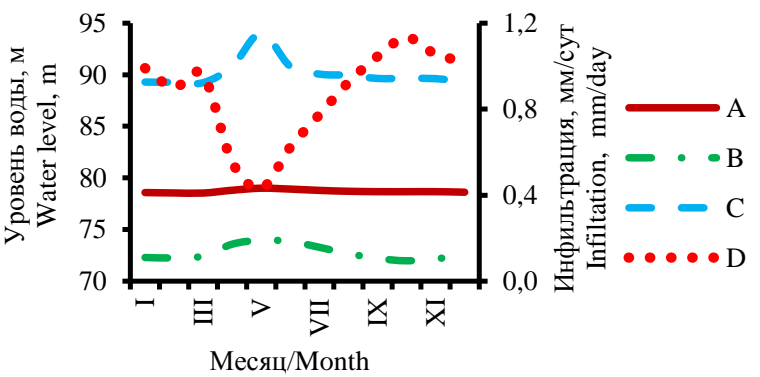

Pис. 4. Внутригодовое изменение (в среднем за многолетний период) уровней подземных (A) и речных вод (B-p. Обь у с. Победа; $C-p$. Шегарка у с. Бабарыкино), инфильтрачии в междуречье ОбъШегарка (D)

Fig. 4. Intraannual change (on the average for the longterm period) of levels of ground $(A)$ and river waters ( $B$ - the $O b$ river at the Pobeda settlement; $C$ - the Schegarka river at the Babarykino settlement), infiltration in the Ob-Schegarka watershed (D) 

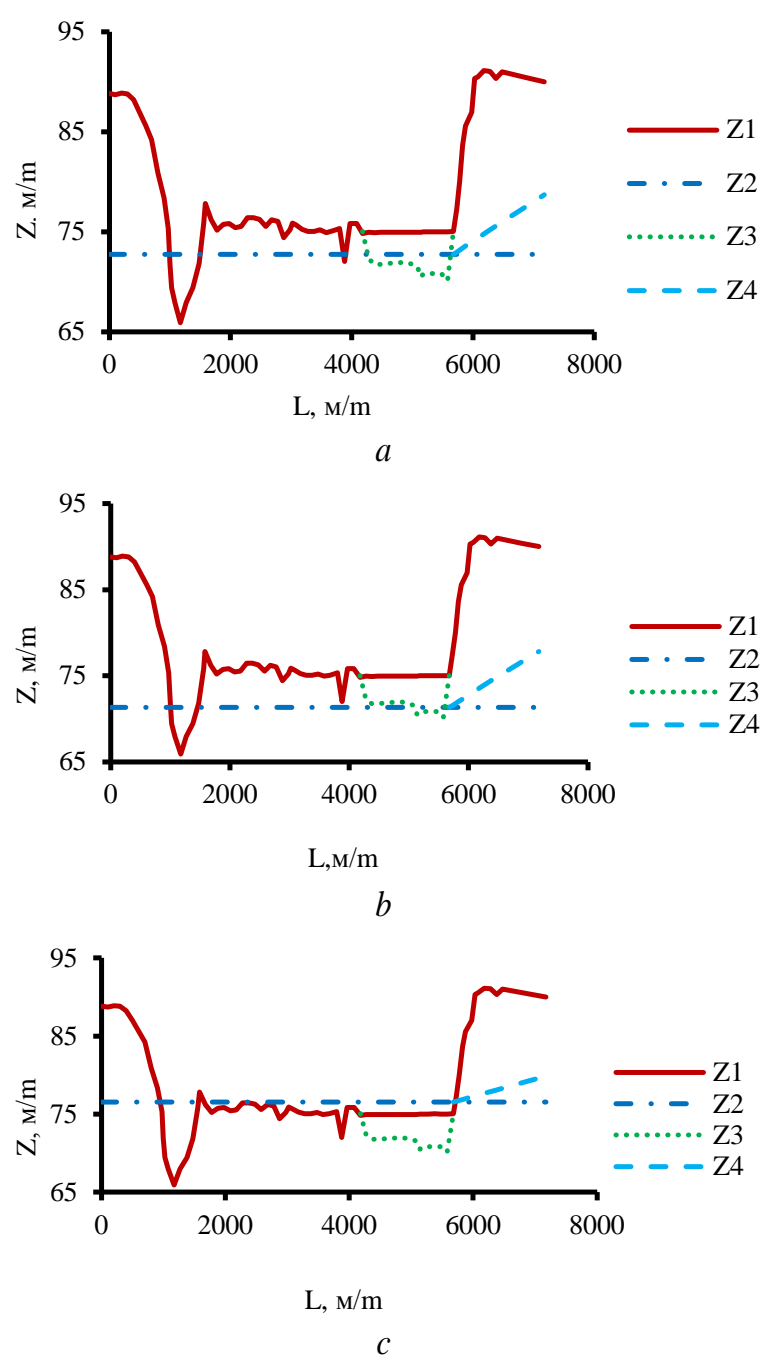

Рис. 5. Схематичный поперечный профиль долины р. Оби у с. Мельниково; L - расстояние от условного начала на правом берегу р. Оби (с. Победа); высотные отметки Z (м в Балтийской системе координат): Z1 - поверхность водосбора, дна р. Оби, ее проток и старии, поверхности Обского болота; Z2 - среднемесячный уровень воды в р. Оби (за 1967-2015 гг.: а-среднемноголетний; $b$ - минимальный среднемесячный; $c$ максимальный среднемесячный); Z3 - дно Обского болота; Z4 - уровень кривой депрессии от скважины 63р у с. Мельниково

Fig. 5. A schematical cross-section structure of the Ob river valley at the Melnikovo settlement; $L$ - distance from the conditional beginning on a right bank of the $\mathrm{Ob}$ river; altitude marks $Z$ ( $m$ in the Baltic system of coordinates): $Z 1$ - surface of the river basin, a bottom of the $\mathrm{Ob}$ river, its channel and floodplain lakes, surface of the Obskoe fen; Z2 - monthly average water level in the $r$. Ob (for 1967-2015: amean; $b$ - minimal monthly; $c$ - maximal monthly); Z3 - Obskoe fen bottom; Z4 - level of ground water at the Melnikovo settlement

Сопоставление среднемесячных уровней подземных вод в палеоген-четвертичном горизонте у с. Мельниково, уровней воды р. Оби у с. Победы и р. Шегарки у с. Бабарыкино (составной схематичный разрез по данным нивелировки долины р. Оби вдоль дороги Томск-Мельниково, опробования торфяной залежи, выполненного у сел Мельниково и Нащеково в 2002-2018 гг. $[11,12]$ и поперечного профиля Обского болота в районе с. Нащеково [9]) подтвердило преобладание нисходящего режима взаимодействия подземных вод водоносных отложений палеогенового возраста и вод р. Оби (рис. 5).

В то же время выявлен ряд важных особенностей связей между речными, подземными и болотными водами. Во-первых, можно предположить, что развитие Обского болота ограничено амплитудой колебания уровней воды р. Оби с учетом продолжительности их стояния, при которых происходит береговая инфильтрация и фильтрация воды в пойме. Вовторых, при низких и средних значениях уровня воды в р. Оби поверхность Обского болота выше отметки сопряжения уровней подземных и речных вод (рис. 5). Вследствие этого существует высокая вероятность фильтрации болотных вод в сторону с. Мельниково на расстояние до 840 м (расчет по уравнению (30) при отсутствии инфильтрации). При очень высоких уровнях воды возможен сценарий, при котором по мере спада половодья пойменные воды сливаются с болотными, вымывают часть органики из торфяной залежи и выносят их в русловую сеть, что подтверждается данными о химическом составе компонентов пойменных экосистем не только на Обском болоте в Западной Сибири, но и в других регионах мира $[9,53]$.

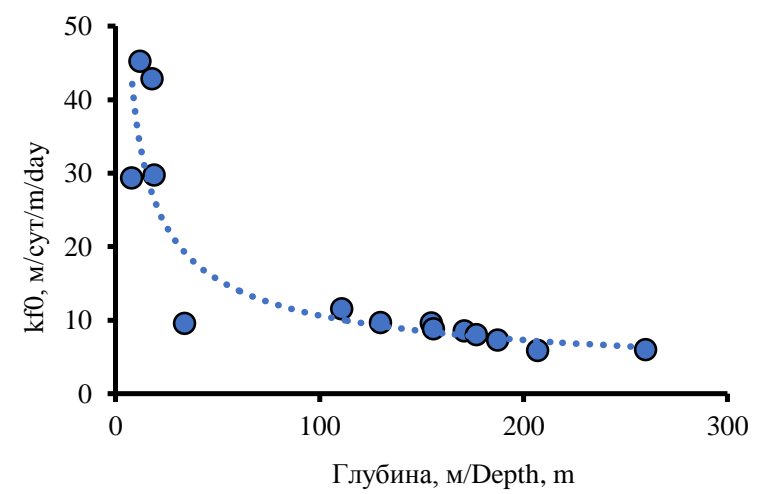

Pис. 6. Изменение средневзвешенного (по мощности отложений) коэффиииента фильтраиии $k_{f 0}$ : $k_{f 0}=130,861 \cdot Z^{0,545}$, где Z - глубина; $R^{2}=0,85$

Fig. 6. Change of average (on capacity of sediments) filtration factor $k_{f 0}: k_{f 0}=130,861 \cdot Z^{-0,545}$, where $Z$ is the depth; $R^{2}=0,85$

В-третьих, расчетное значение коэффициента фильтрации $k_{f 0}=9,88 \mathrm{~m} /$ сут может рассматриваться как средневзвешенное по мощности водоносных отложений. С учетом средних значений фильтрационных свойств этих отложений по разрезу междуречья Икса-Шегарка-Обь $[13,14,16,19]$ глубина зоны активного и условно активного взаимодействия поверхностных и подземных вод составляет 110-120 м (рис. 6) и на значительной части этой территории ограничена снизу малопроницаемыми глинистыми отложениями палеогенового возраста. 


\section{Заключение}

Выполнена количественная оценка элементов водного баланса Баксинского и Обского болот, а также их водосборов (табл. 1-3). Установлено, что при заболачивании с преимущественным распространением низинных болот происходит уменьшение испарения с поверхности и увеличение слоя водного стока. Это приводит к дополнительному переувлажнению примыкающих к болотам суходолам и дальнейшему заболачиванию территории. Ранее аналогичный вывод был получен для олиготрофных участков Васюганского болота в водосборе р. Чая (приток р. Оби).

На эволюцию болотных экосистем при прочих равных условиях существенное влияние оказывает геоморфологическое положение, размер и водный режим рек. Так, развитие Обского болота ограничено рельефом речной долины и амплитудой колебания уровней воды одной из крупнейших рек в мире (р. Оби), обеспечивающих благоприятные условия

\section{СПИСОК ЛИТЕРАТУРЫ}

1. Болотные системы Западной Сибири и их природоохранное значение / О.Л. Лисс, Л.И. Абрамова, Н.А. Аветов, Н.А. Березина, Л.И. Инишева, Т.В. Курнишкова, З.А. Слука, Т.Ю. Толпышева, Н.К. Шведчикова / под ред. В.Б. Куваева. - Тула: Гриф и Кㅇ 2001. -584 с.

2. Eurasian mires of the Southern Taiga Belt: modern features an response to Holocene palaeoclimate / T. Minayeva, W. Bleuten, A. Sirin, E.D. Lapshina // Wetlands and Natural Resource Management. Ecological Studies. V. 190 / Eds. J.T.A. Verhoeven, B. Beltman, R. Bobbink, D.F. Whigham. - Berlin: Heidelberg: Springer-Verlag, 2006. - P. 315-341.

3. Semenova N.M. Western Siberia in the context of global nature conservation concerns // International Journal of Environmental Studies. - 2014. - V. 71. - № 5. - P. 595-604. DOI: 10.1080/00207233.2014.950525

4. Global wetlands: potential distribution, wetland loss, and status S. Hu, Zh. Niu, Y. Chen, L. Li, H. Zhang // Science of the Total Environment. - 2017. - V. 586. - P. 319-327. DOI: 10.1016/j.scitotenv.2017.02.001

5. Sherstyukov A.B. Correlation of soil temperature with air temperature and snow depth // Cryosphere of the Earth. - 2008. - V. 12. № 1. - P. 79-87.

6. Львов Ю.А. Болотные ресурсы // Природные ресурсы Томской области / отв. ред. И.М. Гаджиев, А.А. Земцов. - Новосибирск: Наука, Сибирское отделение, 1991. - С. 67-83.

7. Карта торфяных месторождений Западной Сибири. Масштаб 1:1000000: объяснительная записка / под. ред. Р.Г. Матухина. Новосибирск: Изд-во СО РАН: Филиал «Гео», 2000. - 33 с.

8. Лапшина Е.Д. К экологической оценке современного состояния и истории развития речных пойм // Сибирский экологический журнал. - 1995. - № 4. - С. 297-304.

9. Vegetation characteristics and eco-hydrological processes in a pristine mire in the $\mathrm{Ob}$ River valley (Western Siberia) / A.M. Schipper, R. Zeefat, F. Tanneberger, J.P. van Zuidam, W. Hahne, S.A. Schep, S. Loos, W. Bleuten, H. Joosten, E.D. Lapshina, M.J. Wassen // Plant Ecology. - 2007. - V. 193. - P. 131-145. DOI: $10.1007 / \mathrm{s} 11258-006-9253-\mathrm{x}$.

10. Химический состав вод Обского болота (Западная Сибирь) и его пространственные изменения под влиянием сбросов загрязняющих веществ / О.Г. Савичев, Н.В. Гусева, Е.А. Куприянов, А.А. Скороходова, К.В. Ахмед-Оглы // Известия Томского политехнического университета. - 2013 - Т. 323. - № 1. - С. 168-172.

11. Mineralogical and geochemical features of peat deposit of eutrophic the Obskoye fen in anthropogenous conditions (the Western Siberia) / O.G. Savichev, M.A. Rudmin, A.K. Mazurov, N.G. Nalivaiko, V.I. Sergienko, I.P. Semiletov // Doklady Earth Sciences. - 2020. - V. 492. - P. 1. - P. 320-322. DOI: 10.1134/S1028334X20050219. для развития евтрофной болотной растительности. Для Баксинского болота, расположенного и в долинах малых водотоков и на их водоразделах, характерны условия для развития не только евтрофной, но и мезотрофной растительности.

Взаимодействие поверхностных и подземных вод с разной степенью интенсивности в основном ограничено глубинами 110-120 м (рис. 6). Влияние болотных вод на подземные воды наиболее вероятно в летне-осеннюю межень, когда возможен переток болотных вод в сторону от долинного Обского болота к водоразделу на участках 800-900 м, а также увеличивается инфильтрация (как на Обском, так и Баксинском болотах). Влияние болотных вод, видимо, максимально на спаде высоких половодий, когда происходит сброс водных масс с заболоченной поймы в речное русло.

Работа выполнена при финансовой поддержке гранта РФФИ № 18-55-80015.

12. Условия трансформации коммунально-бытовых сточных вод в болотных экосистемах (на примере Обского болота, Западная Сибирь) / И.С. Иванова, О.Г. Савичев, Е.А. Солдатова, Н.Г. Наливайко, Д.С. Корнеев, Н.В. Гусева, Н.А. Смирнова // Известия Томского политехнического университета. Инжиниринг георесурсов. - 2020. - Т. 331. - № 3. - С. 39-51. DOI $10.18799 / 24131830 / 2020 / 3 / 2530$

13. Горохова И.В., Зятева О.Ф. Геохимия минеральных вод верхнемеловых отложений в с. Мельниково Томской области // Обской вестник. - 2001. - № 1. - С. 110-113.

14. Колоколова О.В. Геохимия подземных вод района Томского водозабора: автореф. дис. ... канд. геол.-минерал. наук. Томск, 2003. $-21 \mathrm{c}$.

15. Льготин В.А., Савичев О.Г., Макушин Ю.В. Многолетние изменения среднесезонных и среднегодовых уровней и температуры подземных вод верхней гидродинамической зоны в Томской области // Геоэкология. - 2010. - № 1. - С. 23-29.

16. Гидрогеология СССР. Т. 16. Западно-Сибирская равнина (Тюменская, Омская, Новосибирская и Томская области) / под ред. В.А. Нуднера. - М.: Недра, 1970. - 368 с.

17. Ресурсы пресных и маломинерализованных подземных вод южной части Западно-Сибирского артезианского бассейна / отв. ред. Е.В. Пиннекер. - М.: Наука, 1991. - 262 с.

18. Гусева Н.В. Механизмы формирования химического состава природных вод в различных ландшафтно-климатических зонах горно-складчатых областей центральной Евразии: автореф. дис. ... д-ра геол.-минерал. наук. - Томск, 2018. - 43 с.

19. Состояние геологической среды (недр) на территории Сибирского федерального округа в 2018 г. Информационный бюллетень. Вып. 15 / под ред. В.А. Льготина. - Томск: Филиал «Сибирский региональный центр ГМСН», ФГБУ «Гидроспецгеология», 2019. - 218 c.

20. Dutova E.M. Geochemistry of fresh groundwater in the AltaiSayan folded area and adjacent areas of the West Siberian plate // Applied Geochemistry. - 2020. - V. 120. - 104673. DOI: 10.1016/j.apgeochem.2020.104673.

21. Торфяные ресурсы Томской области и их использование / Л.И. Инишева, В.С. Архипов, С.Г. Маслов, Л.С. Михантьева. - Новосибирск: Сибирское отделение РАСХН, 1995. - 88 с.

22. Ресурсы поверхностных вод СССР. Т. 15. Алтай и Западная Сибирь. Вып. 2. Средняя Обь. - Л.: Гидрометеоиздат, 1972. $408 \mathrm{c}$.

23. Емельянова Т.Я., Крамаренко В.В. Характеристики фильтрационных свойств торфов Томской области // Обской вестник. - 2001. - № 1. - С. 36-39.

24. Основные гидрологические характеристики. Т. 15. Алтай, Западная Сибирь и Северный Казахстан. Вып. 1. Верхняя и Средняя Обь. - Л.: Гидрометеоиздат, 1979. - 488 с.

25. Научно-прикладной справочник по климату СССР. Сер. 3. Многолетние данные. Ч. 1-6. Вып. 20. Томская, Новосибир- 
ская, Кемеровская области, Алтайский край. - СПб.: Гидрометеоиздат, 1993. - $718 \mathrm{c}$.

26. Long-term dynamics of maximum flood water levels in the middle course of the $\mathrm{Ob}$ River / V.A. Zemtsov, D.A. Vershinin, V.V. Khromykh, O.V. Khromykh // IOP Conference Series: Earth and Environmental Science. Bio-Clim-Land. - 2019. - V. 400. 012004. DOI:10.1088/1755-1315/400/1/012004.

27. Kharanzhevskaya Yu.A., Voistinova E.S., Sinyutkina A.A. Spatial and temporal variations in mire surface water chemistry as a function of geology, atmospheric circulation and zonal features in the south-eastern part of Western Siberia // Science of the Total Environmental. - 2020. - V. 733. - 139343. DOI 10.1016/j.scitotenv.2020.139343

28. СП 33-101-2003. Свод правил по проектированию и строительству. Определение основных расчетных гидрологических характеристик. - М.: Госстрой России, 2004. - 72 с.

29. Методика расчета водохозяйственного баланса водных объектов. - М.: МПР России, 2007. - 41 с.

30. Пособие по определению расчётных гидрологических характеристик / под ред. Т.С. Шмидта. - Л.: Гидрометеоиздат, 1984. - 448 c.

31. Пологова Н.Н., Лапшина Е.Д. Накопление углерода в торфя ных залежах Большого Васюганского болота // Большое Васюганское болото. - Томск: ИОА СО РАН, 2002. - С. 174-186.

32. Manual on Stream Gauging. V. II. Computation of Discharge. WMO. No. 1044. - Geneva, Switzerland: World Meteorological Organization, 2010. - $198 \mathrm{p}$.

33. Мезенцев В.С. Гидрологические расчёты в мелиоративных целях. - Омск: Изд-во Омского СХИ, 1982. - 84 с.

34. Гидрологические расчеты при осушении болот и заболоченных земель / под ред. К.Е. Иванова. - Л.: Гидрометеоиздат, 1963. $-447 \mathrm{c}$

35. Гидрометеорологический режим и водный баланс верховых болот Северо-Запада России (на примере болота Ламмин-Суо) / под ред. С.М. Новикова, В.И. Батуева. - СПб.: Свое издательство, 2019. - 448 c

36. Crop evapotranspiration. Guidelines for computing crop water requirements / R.G. Allen, L.S. Pereira, D. Raes, M. Smith // FAO Irrigation and drainage. Water Resources, Development and Management Service FAO. - 1998. - № 56. - P. 1-276.

37. Орлова В.В. Западная Сибирь. Вып. 4. Климат СССР. - Л.: Гидромеоиздат, 1962. - $360 \mathrm{c}$.

38. Nash J.E., Sutcliffe J.V. River flow forecasting through conceptual models. P. I - A discussion of principles // Journal of Hydrology. 1970. - № 10 (3). - P. 282-290.

39. Руководство по гидрологическим прогнозам. Вып. 1. Долгосрочные прогнозы элементов водного режима рек и водохранилищ. - Л.: Гидрометеоиздат, 1989. - 357 с.
40. Гельфан А.Н. Динамико-стохастическое моделирование формирования талого стока. - М.: Наука, 2007. - 279 с.

41. Иванов К.Е. Водообмен в болотных ландшафтах. - Л.: Гидрометеоиздат, 1975. - $280 \mathrm{c}$

42. A numerical study of the effect of wetland shape and inlet-outlet configuration on wetland performance / N. Sabokrouhiyeha, A. Bottacin-Busolin, J. Savickis, H. Nepf, A. Marion // Ecological Engineering. - 2017. - V. 105. - P. 170-179. DOI: 10.1016/j.ecoleng.2017.04.062.

43. Физика и химия торфа / И.И. Лиштван, Е.Т. Базин, Н.И. Гамаюнов, А.А. Терентьев. - М.: Недра, 1989. - 304 с.

44. Šimůnek J., Van Genuchten M.Th. Modeling nonequilibrium flow and transport processes using HYDRUS // Vadose Zone Journal. 2008. - V. 7. - № 2. - P. 782-797. DOI:10.2136/vzj2007.0074.

45. Шестаков В.М. Гидрогеодинамика. - М.: КДУ, 2009. - 334 с.

46. Мелиорация и водное хозяйство. В 5 т. Т. 3. Осушение / под ред. Б.С. Маслова. - М.: Агропромиздат, 1985. - 447 с.

47. Burakov D.A., Karepova E.D., Shan'ko Yu.V. Model of flow propagation in a river channel taking into account disparity in the "water stage vs water volume» curves corresponding to the rise and recession of a flood wave // IOP Conf. Series: Earth and Environmental Science. Aktru. - 209. - V. 232. - 012002. DOI:10.1088/1755-1315/232/1/012002

48. СП 131.13330.2018. Строительная климатология. - М.: Стандартинформ, 2019. - 153 с.

49. СП 32.13330.2018. Канализация. Наружные сети и сооружения. - М.: Министерство строительства и жилищнокоммунального хозяйства Российской Федерации, 2019. - 86 с.

50. Hendriks M.R. Introduction to physical hydrology. - Oxford; New York: Oxford University Press, 2010. - 331 p.

51. Мелиорация и водное хозяйство. В 5 т. Т. 5. Водное хозяйство / под ред. И.И. Бородавченко. - М.: Агропромиздат, 1988. $399 \mathrm{c}$.

52. Biogeochemistry of holocene peatlands in the baraba forest-steppe (southern West Siberia) / G.A. Leonova, A.E. Maltsev, Yu.I. Preis, L.V. Miroshnichenko // Applied Geochemistry. - 2020. - V. 124. 104811. DOI: 10.1016/j.apgeochem.2020.104811.

53. Effects of flooding on ion exchange rates in an Upper Mississippi River floodplain forest impacted by herbivory, invasion, and restoration / R.M. Kreiling, N.R. de Jager, W. Swanson, E.A. Strauss, M. Thomsen // Wetlands. - 2015. - V. 35. - P. 1005-1012. DOI $10.1007 / \mathrm{s} 13157-015-0675-\mathrm{x}$

Поступила 10.03.2021 2.

\section{Информация об авторах}

Савичев О.Г., доктор географических наук, профессор отделения геологии Инженерной школы природных ресурсов Национального исследовательского Томского политехнического университета.

Ян Хэнь, аспирант отделения геологии инженерной школы природных ресурсов Национального исследовательского Томского политехнического университета. 
UDC 550.42:577.4

\title{
HYDRO-GEOLOGICAL AND HYDROLOGICAL CONDITIONS OF FUNCTIONING OF THE OBSKOE AND BAKSINSKOE FENS (THE SOUTHEAST OF THE WESTERN SIBERIAN PLAIN)
}

\author{
Oleg G. Savichev1, \\ OSavichev@mail.ru \\ Yang Heng', \\ 13698754927@163.com \\ 1 National Research Tomsk Polytechnic University, \\ 30, Lenin avenue, Tomsk, 634050, Russia.
}

\begin{abstract}
Relevance is determined by the important complex role of fens in formation of ecological condition of regions of Western Siberia, including questions of interaction between ground, river and fen waters.

The aim of the research is analysis of hydro-geological and hydrological conditions of functioning of the Obskoe and Baksinskoe fens in southeast of West Siberian plain. The primary tasks are: 1) estimation of elements of water balance of fens and their basins; 2) estimation and analysis of interaction of fen, river and ground waters.

Methods: statistical methods, mathematical modelling of hydro-geological and hydrological processes.

Results and conclusions. The authors have carried out the quantitative estimation of elements of water balance of the Baksinskoe and Obskoe fens and their basins for 1966-2019. Intraannual distribution of infiltration in a paleogene-quaternary deposits of the Ob and Schegarka rivers watershed is determined. Reduction of evaporation from a basin surface and increase of a water flow layer occur at bogging with primary distribution of fens. It results in additional bogging territory. Interaction of surfaces and ground waters with a different degree of intensity is basically limited to depths of 110-120 m. Influence of fen waters on ground waters is probable in summer-autumnal low water. During this period the overflow of fen waters in ground horizons on sites of 800-900 m is possible and the infiltration increases. The influence of fen waters reaches its maximum during the decline of spring flood when water masses are discharged from the swampy floodplain into the river channel.
\end{abstract}

Key words:

The Obskoe fen, the Baksinskoe fen, ground, river and fen waters, water balance, the Western Siberia.

The research was financially supported by the RFBR grants no. 18-55-80015.

\section{REFERENCES}

1. Liss O.L., Abramova L.I., Avetov N.A. Bolotnye sistemy Zapadnoy Sibiri i ikh prirodookhrannoe znachenie [Bog of Western Siberia and their conservation value]. Tula, Grif i K Publ., 2001. $584 \mathrm{p}$.

2. Minayeva T., Bleuten W., Sirin A., Lapshina E.D. Eurasian mires of the Southern Taiga Belt: modern features and response to Holocene palaeoclimate. Wetlands and Natural Resource Management. Ecological Studies. Vol. 190. Eds. J.T.A. Verhoeven, B. Beltman, R. Bobbink, D.F. Whigham. Berlin Heidelberg, Springer-Verlag, 2006. pp. 315-341.

3. Semenova N.M. Western Siberia in the context of global nature conservation concerns. International Journal of Environmental Studies, 2014, vol. 71, no. 5, pp. 595-604. DOI 10.1080/00207233.2014.950525.

4. Hu S., Niu Zh., Chen Y., Li L., Zhang H. Global wetlands: potential distribution, wetland loss, and status. Science of the Total Environment, 2017, vol. 586, pp. 319-327. DOI: 10.1016/j.scitotenv.2017.02.001.

5. Sherstyukov A.B. Correlation of soil temperature with air temperature and snow depth. Cryosphere of the Earth, 2008, vol. 12, no. 1, pp. 79-87.

6. Lvov Yu.A. Bolotnye resursy [Swamp resources]. Prirodnye resursy Tomskoy oblasti [Natural resources of the Tomsk region]. Eds. I.M. Gadzhiyev, A.A. Zemtsov. Novosibirsk, Nauka Publ., Siberian Branch, 1991. pp. 67-83.

7. Karta torfyanykh mestorozhdeniy Zapadnoy Sibiri. Masshtab 1:1000000: obyasnitelnaya zapiska [Map of peat deposits in Western Siberia. Scale 1:1000000: explanatory note]. Ed. by R.G. Matukhin. Novosibirsk, SB RAS Publ. house, Branch «Geo», 2000. 33 p.

8. Lapshina E.D. K ekologicheskoy otsenke sovremennogo sostoyaniya i istorii razvitiya rechnykh poym [To ecological assessment of the current state and history of the development of river floodplains]. Contemporary Problems of Ecology, 1995, no. 4, pp. 297-304.

9. Schipper A.M., Zeefat R., Tanneberger F., Van Zuidam J.P., Hahne W., Schep S.A., Loos S., Bleuten W., Joosten H., Lapshina E.D., Wassen M.J. Vegetation characteristics and eco-hydrological processes in a pristine mire in the Ob River valley (Western Siberia). Plant Ecology, 2007, vol. 193, pp. 131-145. DOI: 10.1007/s11258-006-9253-x.

10. Savichev O.G., Guseva N.V., Kupriyanov E.A., Skorokhodova A.A., Akhmed-Ogly K.V. Chemical composition of the Ob Bog (West Siberia) and its spatial variations under the influence of the discharge of pollutants. Bulletin of the Tomsk Polytechnic University, 2013, vol. 323, no. 1, pp. 168-172. In Rus.

11. Savichev O.G., Rudmin M.A., Mazurov A.K., Nalivaiko N.G., Sergienko V.I., Semiletov I.P. Mineralogical and geochemical features of peat deposit of eutrophic the Obskoye fen in anthropogenous conditions (the Western Siberia). Doklady Earth Sciences, 2020, vol. 492, P. 1, pp. 320-322. DOI: $10.1134 / \mathrm{S} 1028334 \mathrm{X} 20050219$

12. Ivanova I.S., Savichev O.G., Soldatova E.A., Nalivaiko N.G., Korneev D.S., Guseva N.V., Smirnova N.A. Conditions of transformation of municipal wastewater in bog ecosystems (on the example of Obskoe bog, Western Siberia). Bulletin of the Tomsk Polytechnic University. Geo Assets Engineering, 2020, vol. 331, no. 3, pp. 39-51. DOI 10.18799/24131830/2020/3/2530.

13. Gorokhova I.V., Zyateva O.F. Geokhimiya mineralnykh vod verkhnemelovykh otlozheniy v s. Melnikovo Tomskoy oblasti [Geochemistry of mineral waters of the Upper Cretaceous deposits in the village Melnikovo of the Tomsk Region]. Obskoy vestnik, 2001, no. 1, pp. 110-113.

14. Kolokolova O.V. Geokhimiya podzemnykh vod rayona Tomskogo vodozabora. Avtoreferat Diss. Kand. nauk [Geochemistry of groundwater in the Tomsk water intake area. Cand. Diss. Abstract]. Tomsk, 2003. $21 \mathrm{p}$. 
15. Lgotin V.A., Savichev O.G., Makushin Yu.V. Long-term changes in the average seasonal and average annual levels and temperature of groundwater in the upper hydrodynamic zone in the Tomsk region. Geoekologiya, inzhenernaya geologiya, gidrogeologiya, geokriologiya, 2010, no. 1, pp. 23-29. In Rus.

16. Gidrogeologiya SSSR [Hydrogeology of the USSR]. T. 16. Zapadno-Sibirskaya ravnina (Nyumenskaya, Omskaya, Novosibirskaya Tomskaya oblasti) [Vol. 16. The West Siberian Plain (Tyumen, Omskaya, Novosibirsk and Tomsk regions)]. Ed. by V.A. Nudner. Moscow, Nedra Publ., 1970. 368 p.

17. Resursy presnykh i malomineralizovannykh podzemnykh vod yuzhnoy chasti Zapadno-Sibirskogo artezianskogo basseyna [Resources of fresh and low-mineralized groundwater in the southern part of the West Siberian artesian basin]. Ed. by E.V. Pinneker. Moscow, Nauka Publ., 1991. 262 p.

18. Guseva N.V. Mekhanizmy formirovaniya khimicheskogo sostava prirodnykh vod $v$ razlichnykh landshaftno-klimaticheskikh zonakh gorno-skladchatykh oblastey tsentralnoy Evrazii. Avtoreferat Diss. Dokt. nauk [The mechanisms of formation of the chemical composition of natural waters in various landscape and climatic zones of mountain-folded areas of central Eurasia. Dr. Diss. Abstract] Tomsk, 2018. $43 \mathrm{p}$.

19. Sostoyanie geologicheskoy sredy (nedr) na territorii Sibirskogo federalnogo okruga v $2018 \mathrm{~g}$. Informatsionny byulleten [Condition of the geological environment (subsoil) in the territory of Siberian Federal District in 2018. Informational bulletin]. Ed. by V.A. Lgotin. Tomsk, Filial «Sibirskiy regionalny tsentr GMSN», FGBU «Gidrospetsgeologiya» Publ., 2019. Vol. 15. 218 p.

20. Dutova E.M. Geochemistry of fresh groundwater in the AltaiSayan folded area and adjacent areas of the West Siberian plate. Applied Geochemistry, 2020, vol. 120, 104673. DOI: 10.1016/j.apgeochem.2020.104673.

21. Inisheva L.I., Arkhipov V.S., Maslov S.G., Mikhantieva L.S. Torfyanye resursy Tomskoy oblasti $i$ ikh ispolzovanie [Peat resources of Tomsk region and their use]. Novosibirsk, Siberian Branch of the Russian Academy of Agrarian Science Publ. house, 1995. $88 \mathrm{p}$

22. Resursy poverkhnostnykh vod SSSR. T. 15. Altay i Zapadnaya Sibir. Vyp. 2. Srednyaya $\mathrm{Ob}$ [Surface water resources of the USSR. Vol. 15. Altai and Western Siberia. Iss. 2. Mddle Ob]. Ed. by O.N. Panin. Leningrad, Gidrometeoizdat Publ., 1972. 408 p.

23. Emelyanova T.Ya., Kramarenko V.V. Kharakteristiki filtratsionnykh svoystv torfov Tomskoy oblasti [Characteristics of the filtration properties of peat in the Tomsk region]. Obskoy vestnik, 2001, no. 1, pp. 36-39.

24. Osnovnyye gidrologicheskie kharakteristiki. Vol. 15. Altay, Zapadnaya Sibir i Severny Kazakhstan. No. 1. Verkhnyaya i Srednyaya $\mathrm{Ob}$ [Basic hydrological characteristics. Vol. 15. Altai, Western Siberia and Northern Kazakhstan. Iss. 1. Upper and Middle Ob]. Leningrad, Gidrometeoizdat Publ., 1979. 488 p.

25. Nauchno-prikladnoy spravochnik po klimatu SSSR. Ser. 3. Mnogoletnie dannye. Ch. 1-6. Vol. 20. Tomskaya, Novosibirskaya, Kemerovskaya oblasti, Altayskiy kray [Scientific and Applied Climate Handbook. Series. 3. Long-term data. P. 1-6. Vol. 20. Tomsk, Novosibirsk, Kemerovo Region, Altai Territory]. St-Petersburg, Gidrometeoizdat Publ., 1993. 718 p.

26. Zemtsov V.A., Vershinin D.A., Khromykh V.V., Khromykh O.V. Long-term dynamics of maximum flood water levels in the middle course of the Ob River. IOP Conference Series: Earth and Environmental Science. Bio-Clim-Land 2019, vol. 400, 012004. DOI: 10.1088/1755-1315/400/1/012004.

27. Kharanzhevskaya Yu.A., Voistinova E.S., Sinyutkina A.A. Spatial and temporal variations in mire surface water chemistry as a function of geology, atmospheric circulation and zonal features in the south-eastern part of Western Siberia. Science of the Total Environmental, 2020, vol. $733 . \quad 139343 . \quad$ DOI 10.1016/j.scitotenv.2020.139343.

28. SP 33-101-2003. Svod pravil po proektirovaniyu i stroitelstvu. Opredelenie osnovnykh raschetnykh gidrologicheskikh kharakteristik [Code of rules for design and construction. Determination of the main calculated hydrological characteristics]. Moscow, Gosstroy of Russia Publ., 2004. 72 p.

29. Metodika rascheta vodokhozyaystvennogo balansa vodnykh obyektov [Methodology for calculating the water balance of water bodies]. Moscow, MPR of Russia Publ., 2007. 41 p.
30. Posobie po opredeleniyu rasschetnykh gidrologischeskikh kharakteristik [Manual in definition of hydrological characteristics]. Ed. by T.S. Schmidt. Leningrad, Gidrometeoizdat Publ., 1984. 448 p.

31. Pologova N.N., Lapshina E.D. Nakoplenie ugleroda v torfyanykh zalezhakh Bolshogo Vasuganskogo bolota [Carbon accumulation in peat bog deposits of the Great Vasyugan bog]. Bolshoe Vasuganskoe boloto. Sovremennoe sostoyanie i protsessy razvitiya [Big Vasyugan bog. Current status and development]. Tomsk, Institute of Atmospheric Optics SB RAS Publ., 2002. pp. 174-179.

32. Manual on Stream Gauging. Vol. II. Computation of Discharge. WMO-No. 1044. Geneva, Switzerland, World Meteorological Organization, 2010. $198 \mathrm{p}$.

33. Mezentsev V.S. Gidrologicheskie raschety $v$ meliorativnykh tselyakh [Hydrological calculations in reclamation purposes]. Omsk, Omskoy SKHI Publ., 1982. 84 p.

34. Gidrologicheskie raschety pri osushenii bolot $i$ zabolochennykh zemel [Hydrological calculations when draining bogs and wetlands]. Ed. by K.E. Ivanov. Leningrad, Gidrometeoizdat Publ., 1963. $447 \mathrm{p}$

35. Gidrometeorologicheskiy rezhim $i$ vodny balans verkhovykh bolot Severo-Zapada Rossii (na primere bolota Lammin-Suo) [Hydrometeorological regime and water balance of raised bogs of the North-West of Russia (on the example of the Lammin-Suo bog)]. Eds. S.M. Novikov, V.I. Batuev. St-Peterburg, Svoe izdatelstvo Publ., 2019. 448 p.

36. Allen R.G., Pereira L.S., Raes D., Smith M. Crop evapotranspiration. Guidelines for computing crop water requirements - FAO Irrigation and drainage. Paper 56. Water Resources, Development and Management Service FAO. FAO - Food and Agriculture Organization of the United Nations, Rome, 1998. $276 \mathrm{p}$

37. Orlova V.V. Zapadnaya Sibir. Vyp. 4. Klimat SSSR [Western Siberia. Iss. 4. Climate of the USSR]. Leningrad, Gidromeoizdat Publ., 1962. $360 \mathrm{p}$.

38. Nash J.E., Sutcliffe J.V. River flow forecasting through conceptual models. P. I - A discussion of principles. Journal of Hydrology, 1970, no. 10 (3), pp. 282-290.

39. Rukovodstvo po gidrologicheskim prognozam. Vyp. 1. Dolgosrochnye prognozy elementov vodnogo rezhima rek $i$ vodokhranilishch [Guide to hydrological forecasts. Iss. 1. Longterm forecasts of the elements of the water regime of rivers and reservoirs]. Leningrad, Gidrometeoizdat Publ., 1989. 357 p.

40. Gelfan A.N. Dinamiko-stokhasticheskoe modelirovanie formirovaniya talogo stoka [Dynamic-stochastic modeling of the formation of snowmelt runoff]. Moscow, Nauka Publ., 2007. 279 p.

41. Ivanov K.E. Vodoobmen $v$ bolotnykh landschaftakh [Water exchange in mire landscapes]. Leningrad, Gidrometeoizdat Publ., 1975. $280 \mathrm{p}$

42. Sabokrouhiyeha N., Bottacin-Busolin A., Savickis J., Nepf H., Marion A. A numerical study of the effect of wetland shape and inlet-outlet configuration on wetland performance. Ecological Engineering, 2017, vol. 105, pp. 170-179. DOI: 10.1016/j.ecoleng.2017.04.062.

43. Lishtvan I.I., Bazin E.T., Gamayunov N.I., Terentyev A.A. Fizika $i$ khimiya torfa [Physics and chemistry of peat]. Moscow, Nedra Publ., 1989. 304 p.

44. Šimůnek J., van Genuchten M.Th. Modeling Nonequilibrium Flow and Transport Processes Using HYDRUS. Vadose Zone Journal, 2008, vol. 7, no. 2, pp. 782-797. DOI: 10.2136/vzj2007.0074.

45. Shestakov V.M. Gidrogeodinamika [Hydrogeodynamics]. Moscow, KDU Publ., 2009. 334 p.

46. Melioratsiya $i$ vodnoe khozyaystvo. In 5 vol. Vol. 3. Osushenie [Melioration and water management. Vol. 3. Drainage]. Ed. by B.S. Maslov. Moscow, Agropromizdat Publ., 1985. 447 p.

47. Burakov D.A., Karepova E.D., Shan'ko Yu.V. Model of flow propagation in a river channel taking into account disparity in the "water stage vs water volume" curves corresponding to the rise and recession of a flood wave. IOP Conference Series: Earth and Environmental Science. Aktru, 2019, vol. 232, 012002. DOI: 10.1088/1755-1315/232/1/012002.

48. SP 131.13330.2018. Stroitelnaya klimatologiya [Construction climatology]. Moscow, Standartinform Publ., 2019. 153 p.

49. SP 32.13330.2018. Kanalizatsiya. Naruzhnye seti i sooruzheniya [Sewerage. External networks and facilities]. Moscow, Ministerstvo stroitelstva i zhilishchno-kommunalnogo khozyaystva Rossiyskoy Federatsii Publ., 2019. 86 p. 
50. Hendriks M.R. Introduction to physical hydrology. Oxford, New York, Oxford University Press, 2010. $331 \mathrm{p}$.

51. Melioratsiya i vodnoe khozyaystvo. In 5 vol. Vol. 5. Vodnoe khozyaystvo [Melioration and water management. In 5 vol. Vol. 5. Water management]. Ed. by I.I. Borodavchenko. Moscow, Agropromizdat Publ., 1988. 399 p.

52. Leonova G.A., Maltsev A.E., Preis Yu.I., Miroshnichenko L.V. Biogeochemistry of holocene peatlands in the baraba forest-steppe

(southern West Siberia). Applied Geochemistry, 2020, vol. 124, 104811. DOI: $10.1016 /$ j.apgeochem.2020.104811.

53. Kreiling R.M., De Jager N.R., Swanson W., Strauss E.A., Thomsen M. Effects of Flooding on Ion Exchange Rates in an Upper Mississippi River Floodplain Forest Impacted by Herbivory, Invasion, and Restoration. Wetlands, 2015, vol. 35, pp. 1005-1012. DOI: $10.1007 / \mathrm{s} 13157-015-0675-\mathrm{x}$.

Received: 10 March 2021.

\section{Information about the authors}

Oleg G. Savichev, Dr. Sc., professor, National Research Tomsk Polytechnic University.

Yang Heng, graduate student, National Research Tomsk Polytechnic University. 